Review

\title{
Archaeometric Analyses of European 18th-20th Century White Earthenware-A Review
}

\author{
Marino Maggetti \\ Department of Geosciences, University of Fribourg, Chemin du Musée 6, CH-1700 Fribourg, Switzerland; \\ marino.maggetti@unifr.ch; Tel.: +41-26-300-9742
}

Received: 29 April 2018; Accepted: 2 June 2018; Published: 26 June 2018

\begin{abstract}
This study provides an overview of the few archaeometric analyses of European white earthenwares from England, France, Italy, Slovenia, and Switzerland. White earthenwares were an extremely successful mass-product between ca. 1750 and 1900. They became "the porcelain of the poor man" and replaced the older traditional pottery such as faïence. The invention of this new ceramic type took place simultaneously in England and France shortly before 1750. Contemporary recipes can be compared to the analytical results of these products. The ceramic bodies are, according to the chemical (X-ray fluorescence (XRF), scanning electron microscope-energy-dispersive X-ray spectroscopy (SEM-EDS), particle-induced X-ray emission-proton-induced X-ray emission (PIXE-PIGE) and microscopic analyses (scanning electron microscope-back scatter detector (SEM-BSE), artificial mixtures of clay + quartz + flux. Various techniques can be recognized. In England, a blend of a CaO-poor clay (with illite flux) + calcined flint is typical of the so-called creamware, whereas supplementary fluxes (Cornish stone) resulted in the Queen's ware. In France and Central Europe, $\mathrm{CaO}-$ poor clays were mixed with grog (Paris) or with calcined flint/quartz pebbles/sand or with carbonates + Alk-/ Pb-frits (Lorraine). Swiss CaO-rich bodies may contain bone ash or dolomite as flux. The products of the individual factories can be differentiated on the basis of their chemical composition. Micromorphological and chemical analyses revealed intensive physico-chemical reactions between the glaze and the body.
\end{abstract}

Keywords: white earthenware; ceramic body; glaze; chemical analysis; microscopic analysis

\section{Introduction}

White earthenware is a particular class of ceramics with a white, porous body and normally covered with a lead glaze. Such objects were manufactured for instance in France in the 16th century. The so-called Saint-Porchaire ware, a technologically outstanding Renaissance ceramic type, created during a brief period in the mid-sixteenth century [1], or the extra white pastes produced by Bernard Palissy (1510?-1590) in his Paris workshop in the years 1567-1586 [2,3]. However, these costly wares were restricted to the noble classes.

In the first decades of the 18th century, new and much cheaper bodies were invented roughly simultaneously in England and France [4]. English potters preferred CaO-poor clays, abundant in England, to create new ceramic types, but French potters used both $\mathrm{CaO}$-poor and $\mathrm{CaO}$-rich white firing raw materials. In both countries, production was soon running on an industrial scale, so the objects could be named white-bodied industrial earthenware.

In Staffordshire's early 18th century thriving pottery district (Figure 1) local competition to whiten the pastes to emulate the whiteness of porcelain led around 1720 to the creation of the immensely successful white salt-glazed stoneware or common ware [5,6]. Between 1720 and 1740, further experiments with other raw materials such as the Al-rich and highly plastic Devon or Dorset ball clays gave birth to another body called creamware or cream colored ware, bisque fired at $1100-1200{ }^{\circ} \mathrm{C}[7,8]$. The lead 
oxide used to glaze the body was contaminated with iron that imparted a creamy tint to the glaze thus giving it its descriptive name. Addition of calcined and milled flint improved the solidity and whiteness of the creamware. In his manufactory at Burslem, Josiah Wedgwood I (1730-1795) produced ca. 1761 a new kind of creamware body. He added kaolinite and feldspar to the paste and obtained a much whiter and harder body than the usual creamware. This was named Queen's ware in 1765 [9], see Figure 2. Around 1775, cobalt oxide was added to the raw glaze mix to optically mask the yellow iron hue of the fired glaze. These objects were christened pearlware or china glaze ware.
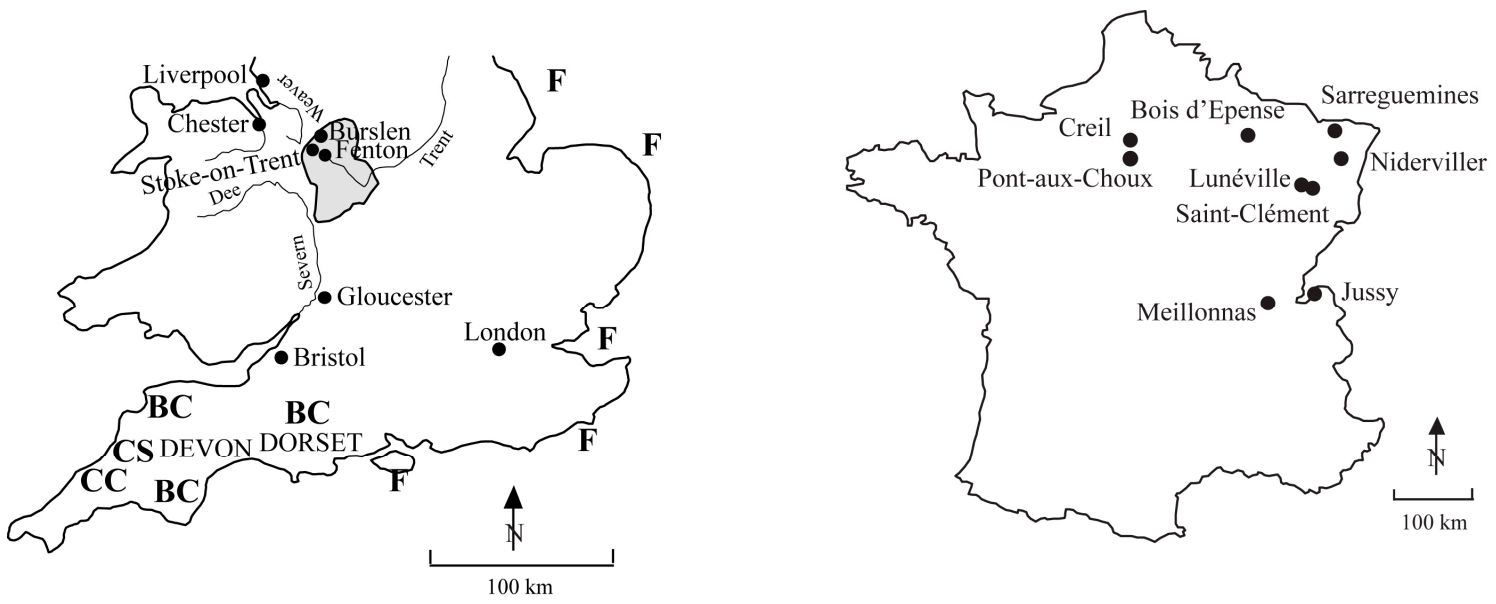

Figure 1. Maps of England and France with manufacturing sites mentioned. The former shows the sources of ceramic raw materials used in 18th century Staffordshire (grey area) potteries. BC = ball clay, $\mathrm{CC}=$ china clay, $\mathrm{CS}=$ Cornish stone, $\mathrm{F}=$ flint

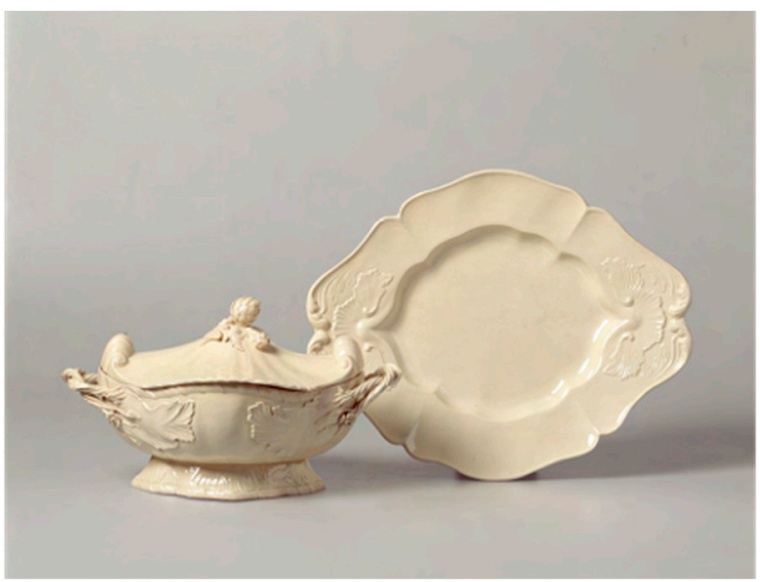

(a)

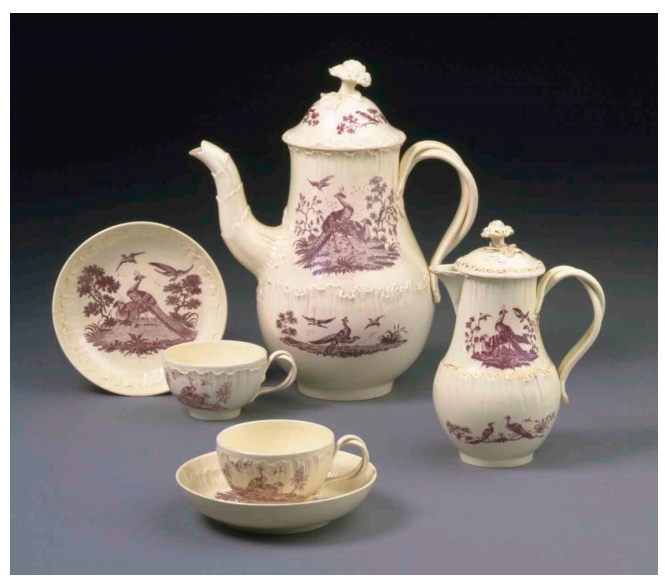

(b)

Figure 2. English white earthenware. (a) Tureen with supporting plate. Wedgwood Queen's ware, Etruria manufactory, ca. 1770. Tureen H: $20.5 \mathrm{~cm}$, L: $36 \mathrm{~cm}$. Plate L: $43 \mathrm{~cm}$. Photo Jacques Pugin. (c) Musée Ariana, Switzerland; (b) Queen's ware service, on-glaze transfer-printed with purple pigments. Josiah Wedgwood and Sons Ltd. (Etruria, Stoke-on-Trent, UK), printed in Liverpool by Guy Green, ca. 1775. Reg. No. 414:1157/B\&C-1885. (C) Victoria and Albert Museum, London.

French white earthenware originated during the years 1730-1750 in Central (Paris) und Eastern (Lorraine) France. On 27 June 1743, Claude-Imbert Gérin was granted a 10-year privilege to found a royal manufactory in Paris "de la fayance a l'imitation de celle d'angleterre" (of fayance imitating that of England) [4] (p. 84). It was established at the Rue de Charenton and transferred to a larger place near the bridge Pont-aux-Choux in 1749 [10-12]. This new paste was probably created as early as 
1740. It was made of $66 \%$ Moret clay, a local white $\mathrm{Al}_{2} \mathrm{O}_{3}$-rich and $\mathrm{CaO}$-poor clay from Montereau, and 33\% calcined Moret clay (grog) [13] (p. 60). Its tableware was known for its typical rice-grain or barley-corn molded motif. This motif was probably derived from English salt-glazed wares, copied 1750-1756 at Pont-aux-Choux (Figure 3a) and in use until the closing of the factory in 1788 [4,14]. In Lorraine, Jacques II Chambrette managed to produce in the town of Lunéville a CaO-rich (calcareous) white earthenware, called terre de pipe (Figure 3b), perhaps as early as 1731 [15]. His success triggered the creation of 23 manufactories in Lorraine during the 18th century $[4,15]$. Their whitewares were generally made up of four main ingredients: (1) $\mathrm{Al}_{2} \mathrm{O}_{3}$-rich refractory clay, (2) chalk, (3) $\mathrm{Pb}$-frit, and (4) calcined flint or quartz pebbles [16]. Three periods can be distinguished in the historical evolution of French white earthenware [4]: (1) 1743-1790: the coexistence of $\mathrm{Al}_{2} \mathrm{O}_{3}$-rich \& CaO-poor and CaO-rich white earthenware bodies, (2) 1790-1830: the improvement of the non-calcareous wares by adding calcined flint or quartz pebbles to the paste, resulting in the so-called cailloutage body, and (3) after 1830: a further improvement of the non-calcareous bodies by admixing kaolinite and feldspar to the paste [4]. Visibly, the French potters could not compete as they were technologically at least 50 years behind. In the late 18th and early 19th centuries, many white earthenware factories blossomed in France and the neighboring countries such as Germany [17], Italy [18], and Switzerland [19].

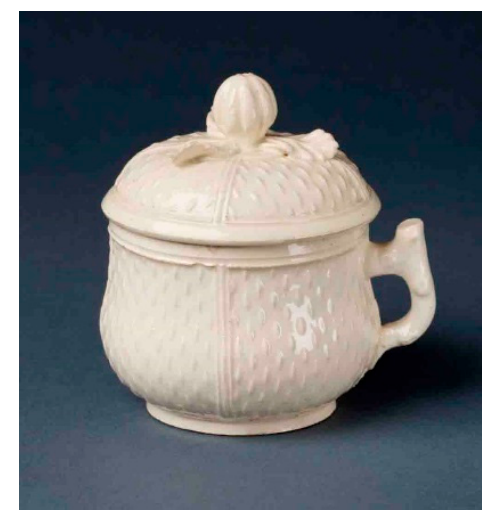

(a)

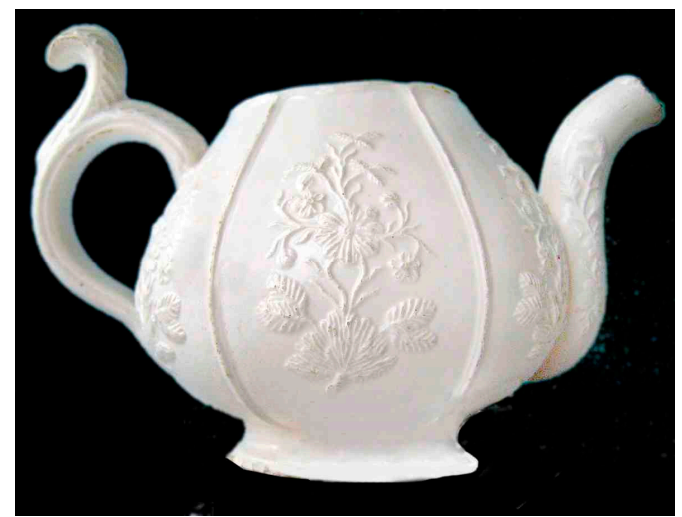

(b)

Figure 3. French white earthenware. (a) Gravy (meat juice) pot with cover. Molded decoration with rice grain or barley corn patterns. Attributed to the Pont-aux-Choux pottery factory, ca. 1760-1780. Reg. No. C.127\&A-1945. (C) Victoria and Albert Museum, London. (b) Teapot attributed to Lunéville. Molded decoration with flowers. Terre de pipe. Late 18th century. H: $12 \mathrm{~cm}$. () M. Maggetti, Private collection. [16] (An. No. TBL 1).

\section{Nomenclature}

The English (stonepaste, creamware, Queen's ware), German (Steingut) and Italian (terraglia) nomenclature of this particular class of ceramics, made up of synthetic and porous pastes turning white during firing, is rather simple. In France, however, the nomenclature is more complex.

\subsection{French Nomenclature in the 18th and 19th Centuries}

The oldest book dealing with this kind of material was published anonymously [20], but attributed by Brongniart to Oppenheim [21]. He quotes that the white pottery in the English manner is a faïence fine covered with a transparent glaze, known as fine pottery, white faïence, English earthenware, terre de pipe, English faïence, white earthenware, and cailloutage. The term terre de pipe is a synonym for English faïence and was continuously used in the French technical treatises of the early 19th century [20,22,23]. Brongniart (1770-1847), director of the Royal porcelain manufactory of Sèvres from 1800 to 1847 , classified white earthenwares into three types: (1) the so-called terre de pipe ("faïnce fine marnée") with a calcareous body; (2) the creamware or cream-colored earthenware ("faïence fine cailloutée, cailloutage, 
terre anglaise, poterie façon anglaise"), with a CaO-poor (non-calcareous) body; and (3) the semi-porcelain ("porcelaine opaque, ironstone, faïence fine dure, faïence fine feldspathique, lithocéram"), also with a CaO-poor body [23]. Evidently, the French terminology is complex and confusing $[4,16,24,25]$. The actual most popular French term faïence fine-designating a white, porous body covered with a transparent lead-glaze-should be replaced by the more neutral term terre blanche, since a French faïence has a colored, porous body and a white tin (cassiterite, $\mathrm{SnO}_{2}$ ) opacified glaze.

\subsection{Whitewares, White Earthenwares and Porcelains}

Clay-derived ceramic objects with a white body (whitewares) belong either to the family of white earthenware, if their water adsorption is above $2 \%$, or to the porcelains, with water adsorption below $2 \%$ [26].

\subsection{Archaeometric Nomenclature}

A priori, scientists know nothing about the ingredients of a whiteware's paste. The nomenclature should therefore be based on the microscopic aspects and the chemical analyses of the final product. Irrespective of the specific type, whitewares are made up of two or three fundamental ingredients: (1) plastic raw materials such as kaolin, China clay or ball clays (highly plastic, refractory and kaolinitic clays); (2) non plastic materials such as calcined and finely milled flint, quartz pebbles and quartz-rich sands or ground fired clay (grog); and (3) fluxing materials such as illite, lime, chalk, limestone, dolomite, magnesite (giobertite), feldspar, Cornish stone, pegmatite, lead frit, alkaline glass, fusible sand and bone ash. In practice, one or more of these three ingredients can be mixed.

All chemical analyses revealed that a white earthenware body consists of three to four dominant oxides: $\mathrm{SiO}_{2}, \mathrm{Al}_{2} \mathrm{O}_{3}, \mathrm{CaO}$, and $\mathrm{MgO}$. The classification can therefore be based on these four constituents. A white earthenware with $80-85 \mathrm{wt} \% \mathrm{SiO}_{2}$ or higher will be classified as siliceous white earthenware. Its body consists mainly of crushed quartz grains with little or no clay, all welded together by a vitreous flux [27-29]. This pottery type is also named stonepaste.

A white earthenware with $\mathrm{SiO}_{2}$ lower than 80-85 wt \% belongs either to the aluminous white earthenwares (Al white earthenware), with no or very little $\mathrm{CaO}$ and $\mathrm{MgO}$ (maximum 3-4 wt \%), or to the $\mathrm{CaMg}$ white earthenwares with conspicuous amounts of $\mathrm{CaO}$ and $\mathrm{MgO}$. Both oxides are derived either from carbonate rocks (limestone, dolostone) or from carbonate minerals (calcite $\mathrm{CaCO}_{3}$, dolomite $\mathrm{CaMg}\left(\mathrm{CO}_{3}\right)_{2}$, Magnesite $\left.\mathrm{MgCO}_{3}\right)$ or their mixed end members. The nature of the carbonate ingredients can be ascertained with a $\mathrm{MgO}-\mathrm{CaO}$ plot (Figure 4).

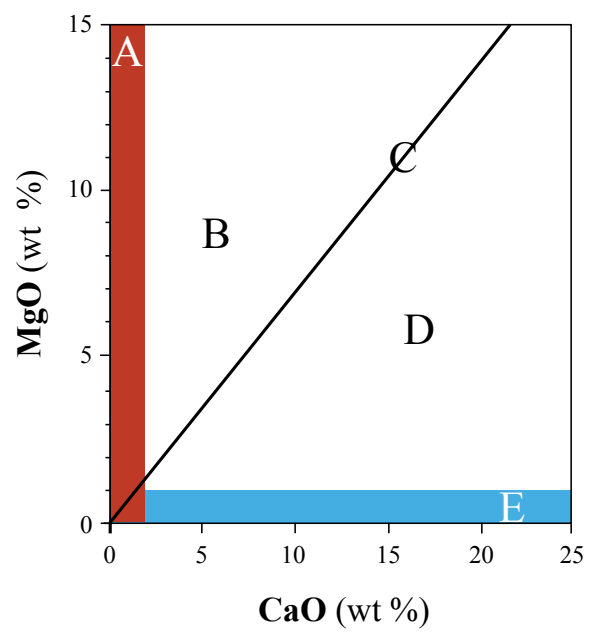

Figure 4. Binary diagram $\mathrm{MgO}-\mathrm{CaO}$ to ascertain the nature of the Ca-Mg ingredients in the pastes, see explanation in the text. 
Pastes with magnesite alone should plot on the ordinate, but in reality, there is always some $\mathrm{CaO}$ present that will enlarge the ordinate to the red area $\mathrm{A}$. A high dosage of magnesite results in a placement of the analysis towards the very top of the ordinate or the red area, a weak one by a downward shift on that line/area. The central black line $C$ connects the zero point with the projection pole of the mineral dolomite, which lies here outside the diagram. Ceramic bodies plotting on this line show calcium and magnesium oxide content, which are explained by the addition of the mineral dolomite or the rock dolostone to their paste exclusively, without other ingredients containing calcium or magnesium in their chemical formula. On the other hand, if the calcium is only due to the presence of the mineral calcite (or of a rock containing this mineral like chalk, limestone, marble) or of another Ca-phase like gypsum $\mathrm{CaSO}_{4} \cdot 2 \mathrm{H}_{2} \mathrm{O}$, in the recipe, without or very little $\mathrm{MgO}$, all the points will be on the horizontal abscissa or in the blue area $\mathrm{E}$. The compositions dependent on the simultaneous presence of these carbonates in the paste's recipe will have their projection point in the areas between the black "dolomite" line and the abscissa or the ordinate. The space B to the left of the black central line will accommodate all compositions derived from mixtures of $\mathrm{Ca}-\& \mathrm{CaMg}-\&$ dominant $\mathrm{Mg}$-carbonates, the space D mixtures with dominant $\mathrm{Ca}$-carbonates. This binary diagram allows the classification of the CaMg white earthenwares in four groups: (A) magnesitic, (B) $\mathrm{MgCa}$; (C) dolomitic; (D) $\mathrm{CaMg}$, and (E) calcitic white earthenwares.

\section{Production of White Earthenwares: Historical and Technical Aspects}

\subsection{Some Manuscript Sources}

No such sources seem to have been published for England. In France, the oldest recipes can be found in the short chapter "De la terre dangleterre blanche, et marbrée" in Pierre Paul Caussy's manuscript, probably written in the time span 1735-1747 [30]. He coined the term terre de pipe. Terre de pipe recipes of other French manufactories (Aprey, Audun-la-Tiche, Jussy Saint-Clément and Septfontaines) are known [4,24,31]. A summary is given in [16] (p. 768). Some Swiss recipes of the 18th to the 19th century are reported for CaO-rich white earthenwares produced in Carouge [32], Lenzburg [33], Les Pâquis [34], Luzern [35], Matzendorf [35], and Nyon [32]. Late 19th century recipes for $\mathrm{CaO}$-poor white earthenware of the Carouge manufactory are presented in [36,37]. As for Italy, the recipe of a CaO-rich white earthenware is known for the Torino manufactory [37,38].

\subsection{The Production Technique of White Earthenware According to Oppenheim [20]}

In the title of his book, Oppenheim calls himself a "former manufactory director", but we know nothing about his life. He gives a detailed account of how to produce poterie blanche, façon anglaise; i.e., $\mathrm{CaO}$-poor white earthenware.

According to him, the mixing of clay and flint is the most sensitive phase of the preparation. Not enough flint would cause a high quantity of pieces to break after firing, and too much of it would produce fragile pieces due to their high porosity. For France, the name of about fifteen places where white firing clays can be found are given, along with places near Antwerp and in the region of Cologne (Germany). The presence of chalk in the clay could cause a distortion of the shape during firing. With Montereau clay, first fired at a temperature of $100^{\circ}$ Wedgwood, one sevenths part of flint is added, according to the following recipe (in parts): 87 of washed plastic Montereau clay +13 of pounded flint [23]. After drying, the unfired pieces are placed in saggars made of clay containing neither iron nor chalk, including a strong proportion of grog of a similar composition.

The first (bisque) firing occurs in a cylindrically formed kiln with a dome roof. It has four to eight grated fireboxes placed outside. In France, the fuel is wood, in England coal. After the low fire (petit feu), which lasts two to three hours, more wood of a larger size is added for another thirty to forty hours, then comes the hard firing (grand feu), a period of twenty to thirty hours characterized by a long and intense flame obtained by laying the wood in embankments. The inside of the kiln has then turned 
white and the firing of the ware is over. In summary, the first firing lasts fifty to seventy hours in all-the more flint there is, the longer the firing. When firing is terminated, the kiln is left to cool down.

The glaze is a mixture of ground calcined flint, minium $\left(\mathrm{Pb}_{3} \mathrm{O}_{4}\right)$ and potash, an impure $\mathrm{K}$-carbonate obtained through the combustion of wood. For a Montereau clay with $1 / 7$ calcined flint, first fired at a temperature of $100^{\circ}$ Wedgwood, the glaze recipe is (in parts): 8 of white sand + 10 of minium +5 of potash and $1 / 1000$ of the whole of cobalt. The mixture is placed in a closed crucible and fritted in the kiln. Another recipe consists in making a preliminary frit with white sand and an equivalent quantity of minium mixed with two parts of commercial potash, from which two glazes can be obtained. Glaze 1 (parts): 2 of vitrified mass +1.5 of minium $+1 / 16$ of lead-free white glass, all fired at $12^{\circ}$ Wedgwood. Glaze 2 (parts): 2 of vitrified mass +1 of lead oxide (litharge d'or) $+1 / 16$ of white glass, all fired at $20^{\circ}$ Wedgwood.

The second (glaze) firing occurs in a kiln similar to the first one, but smaller. The firing time only lasts from sixteen to twenty-four hours, with twelve to eighteen hours of low fire and four to six hours of hard firing periods. The firing temperatures are lower than those of the first firing, and do not surpass $15-18^{\circ}$ Wedgwood for the French glazes and $27-30^{\circ}$ Wedgwood for the English ones [22].

\subsection{French and German Technical Handbooks of the First Half of the 19th Century}

Other French technical commentaries followed in 1827 [23] and 1830 [22]. They do not differ from Oppenheim, giving only some minor details about the French technique (cailloutage) for the English creamware type. Bastenaire Daudenart's book was soon translated into German by the director of the Royal porcelain manufactory of Berlin [39]. Boudon de Saint-Amans, who worked in the Royal porcelain manufactory of Sèvres, gives a thorough explanation of how creamware was produced in England [40]. In 1835, another treatise in German was published [41]. Brongniart's first edition of his masterpiece work appeared in 1844 finally [21]. It was to become the reference book for French potters. For France, he focused mainly on CaO-poor white earthenware with some mention to Lunéville, Mettlach, Sarreguemines, Saint-Clément and Vaudrevange as places where CaO-rich (calcareous) earthenware was still produced. Only one recipe-Brongniart does not say where it comes from-is given for such a paste (in parts): 85.4 of clay $\left(75 \mathrm{wt} \% \mathrm{SiO}_{2}, 25 \mathrm{wt} \% \mathrm{Al}_{2} \mathrm{O}_{3}\right)+13$ of flint +1.6 of lime. Visibly, this is a creamware and not a calcareous paste as it contains very little calcium. He compiled eight recipes of English white earthenwares (creamware, Queen's ware) consisting of differing mixtures of ball clays, clays, kaolin, calcined flint, altered feldspar, altered pegmatite and shavings, summarized in [25] (p. 158). In the first decades of the 19th century, CaO-rich white earthenware bodies were obviously antiquated and not worth reporting in technical treatises.

\subsection{Firing Temperatures}

The temperatures of the first and second firing were estimated in the 18th and 19th centuries with the so-called Wedgwood pyrometer [23,42]. In Table 1, these assumptions are compared with the ${ }^{\circ} \mathrm{C}$ of today [43].

Table 1. Firing temperatures.

\begin{tabular}{|c|c|c|c|c|c|c|}
\hline \multirow[t]{2}{*}{ Type } & \multirow[t]{2}{*}{ Flux } & \multirow{2}{*}{$\begin{array}{c}\mathrm{CaO} \& \mathrm{MgO} \\
\text { wt } \%\end{array}$} & \multicolumn{2}{|c|}{ Bisque Firing } & \multicolumn{2}{|c|}{ Glaze Firing } \\
\hline & & & Pyrometer & ${ }^{\circ} \mathrm{C}$ & Pyrometer & ${ }^{\circ} \mathrm{C}$ \\
\hline \multirow[t]{2}{*}{$\mathrm{CaO}$-poor } & Clay & & $\begin{array}{c}\text { [23]: } 90-100 \\
{[23,42]: \text { ca. } 60}\end{array}$ & $1200-1250$ & $\begin{array}{c}\text { [23]: ca. } 12,27-30 \\
\text { [42]: } 20-25\end{array}$ & 900 \\
\hline & Feldspar & & [42]: 89-100 & 1140-1300 & [23]: $27-30$ & $1000-1140$ \\
\hline \multirow{2}{*}{$\begin{array}{c}\mathrm{CaO}-\& \\
\text { MgO-rich }\end{array}$} & Ca- and & $4-7$ & & 1060-1050 & & $900-1000$ \\
\hline & Mg-carbonate & $13-14$ & $\begin{array}{l}\text { [23]: 25-30, } \\
{[42]:<25-30}\end{array}$ & ca. 980 & {$[42]:<25-30$} & ca. 980 \\
\hline
\end{tabular}




\section{Analytical Studies-A Summary}

A discussion of the chemical analyses of Saint-Porchaire and Palissy ware bodies and glazes can be found in [6]. This chapter will focus on all published scientific analyses of English, French, Italian, Slovenian, and Swiss white earthenwares (mostly tableware).

\subsection{English White Earthenware}

There are surprisingly few archaeometric studies of English specimens. The chemical composition of a Staffordshire (Wedgwood?) paste was published as early as 1830 [22] and a single Wedgwood pottery analysis was reported in 1857 [42]. Recent studies dealt with five sherds of unmarked eighteenth-century Staffordshire white bodies of unspecified typology and provenance (creamware, Queen's ware, pearlware, consumption site, production site, collection?) [44], and three fragments bearing the Wedgwood impressed stamp from archaeological findings in Bern, the Swiss capital, and produced between 1769 and 1832 [25].

\subsubsection{Body: Microstructures, Chemical Compositions and Technical Aspects}

The 18th century Staffordshire bodies show "abundant angular quartz in fine-textured, interconnecting relict-clay-glass phases" [44]. Scanning electron microscope-energy-dispersive X-ray spectroscopy (SEM-EDS) analyses reveal (wt \%) 76.2-78.6 $\mathrm{SiO}_{2}, 17.2-19.6 \mathrm{Al}_{2} \mathrm{O}_{3}$ and 1.5-1.8 $\mathrm{K}_{2} \mathrm{O}$, the other oxides having maximum values not higher than 1 (Table 2).

Table 2. Chemical compositions (Min.-Max.) of English and French CaO-poor white earthenwares. Oxides and chlorine in $\mathrm{wt} \%$, other elements in ppm.

\begin{tabular}{|c|c|c|c|c|c|c|}
\hline & Staffordshire & Wed & ood & Pont-aux-Choux & Creil & Sarreguemines \\
\hline Date & 18th century & 1769-1832 & $?$ & End 18th century & $1797-1832$ & ca. 1820 \\
\hline $\mathrm{N}$ analyses & 5 & 3 & 1 & 5 & 2 & 1 \\
\hline Method & SEM-EDS & $\mathrm{XRF}$ & PIXE-PIGE & XRF & XRF & XRF \\
\hline Reference & [44] & [25] & [45] & [16] & [25] & [16] \\
\hline $\mathrm{SiO}_{2}$ & $76.2-78.6$ & $73.7-75.52$ & 70.2 & $60.72-63.29$ & $77.02-79.37$ & 61.14 \\
\hline $\mathrm{TiO}_{2}$ & $0.4-1.0$ & $0.75-1.08$ & 0.65 & $0.74-0.92$ & $0.59-0.62$ & 1.06 \\
\hline $\mathrm{Al}_{2} \mathrm{O}_{3}$ & $17.2-19.6$ & $18.45-21.74$ & 20.6 & $31.49-34.02$ & $17.02-19.18$ & 29.95 \\
\hline $\mathrm{FeO}, \mathrm{Fe}_{2} \mathrm{O}_{3}$ & $0.8-1.0$ & $0.54-0.68$ & 0.5 & $1.17-1.29$ & $0.65-0.71$ & 1.43 \\
\hline $\mathrm{MgO}$ & $<0.2-0.4$ & $0.11-0.14$ & 0.35 & $0.01-0.12$ & $0.08-0.10$ & 0.52 \\
\hline $\mathrm{CaO}$ & $0.4-0.5$ & $0.50-0.90$ & 3.50 & $0.57-0.75$ & 0.4 & 0.38 \\
\hline $\mathrm{Na}_{2} \mathrm{O}$ & $<0.2-0.5$ & $0.26-0.33$ & 0.42 & $0.83-0.94$ & $0.19-0.29$ & 1.95 \\
\hline $\mathrm{K}_{2} \mathrm{O}$ & $1.5-1.8$ & $0.92-1.06$ & 1.35 & $0.61-0.76$ & $0.34-0.37$ & 3.60 \\
\hline $\mathrm{P}_{2} \mathrm{O}_{5}$ & & $0.05-0.06$ & & $0.35-0.71$ & $0.12-0.13$ & 0.10 \\
\hline $\mathrm{SO}_{3}$ & & & 1.62 & & & \\
\hline $\mathrm{Cl}$ & & & 0.23 & & & \\
\hline $\mathrm{Ba}$ & & $203-226$ & & $261-354$ & $128-132$ & 646 \\
\hline $\mathrm{Cr}$ & & $76-85$ & & $157-208$ & $87-90$ & 246 \\
\hline $\mathrm{Cu}$ & & $27-67$ & & $2-12$ & 10 & 33 \\
\hline $\mathrm{Nb}$ & & $12-20$ & & $17-23$ & 17 & 20 \\
\hline $\mathrm{Ni}$ & & $17-25$ & & $76-104$ & $18-19$ & 66 \\
\hline $\mathrm{Pb}$ & & $98-643$ & 4641 & 654-2041 & $1744-3764$ & 503 \\
\hline $\mathrm{Rb}$ & & $49-67$ & & $34-52$ & $11-17$ & 229 \\
\hline $\mathrm{Sr}$ & & 89-106 & & $642-1156$ & $211-227$ & 148 \\
\hline Y & & $19-22$ & & $49-67$ & $53-73$ & 21 \\
\hline $\mathrm{Zr}$ & & 159-193 & & $212-228$ & $101-110$ & 191 \\
\hline $\mathrm{Zn}$ & & & 100 & & & \\
\hline
\end{tabular}

The microstructure (Figure 5a) of the three Wedgwood specimens (consumption site, marked) consist of: (1) angular $\mathrm{SiO}_{2}$ fragments with maximum diameters of 40-50 $\mu \mathrm{m}$; (2) Rare inclusions type $\mathrm{A}, \mathrm{B}$, and $\mathrm{C}$; and (3) a fine-grained, porous, and felt-like matrix (Figure 5). $\mathrm{The}^{\mathrm{SiO}} 2$ particles are characterized by a multitude of internal cracks and sub-domains in the range of ca. $2 \mu \mathrm{m}$. They consist of quartz, as shown by the X-ray diffraction (XRD) recordings. Other $\mathrm{SiO}_{2}$ polymorphs such as cristobalite or tridymite may well be present, but their amounts would then be below the XRD detection limit. The peculiar internal structure is characteristic of calcined flint, because calcined 
quartz pebbles or quartz sands show a homogeneous microstructure (see below). Inclusion type A and B have typical features of grog or ceramoclast [46], such as different chemical composition and microstructure compared to the surrounding body, angular shapes, and drying cracks around the inclusion $[47,48]$. The differences in their chemical composition as compared to the Wedgwood bodies exclude that they may represent former bisques or paste shavings. The angular type A fragments show a glassy matrix with embedded needles of mullite, similar to highly fired hard paste porcelain bodies. Their chemical composition is compatible with a derivation from former Si-rich ball clays or a mix of those clays with Cornish stone. The type B inclusions are rounded to subangular with a phyllosilicate textural aspect. These microstructural aspects and their higher alumina content compared to the type $\mathrm{A}$ inclusions indicate their derivation from a kaolinite rich (high $\mathrm{Al}$ ) clay, that is an $\mathrm{Al}_{2} \mathrm{O}_{3}$-rich ball clay. Both types were fired and crushed before admixing to the matrix clays. The type $\mathrm{C}$ inclusions are round pores of former carbonate inclusions (limestones) with characteristic calcium-rich rims up to $12.7 \mathrm{wt} \% \mathrm{CaO}$, relicts of the original clay(s). The matrices, that is, the former clays, of the Wedgwood samples are chemically similar and are made up of dominantly two oxides, $\mathrm{SiO}_{2}$ and $\mathrm{Al}_{2} \mathrm{O}_{3}$. Their overall SEM-EDS analytical data matches those of kaolinitic-illitic clays of the ball clay type. They may represent: (1) a single, $\mathrm{SiO}_{2}$-rich ball clay; (2) or a batch of one or more ball clays; (3) or a batch of one or more ball clays with one or more china clays. The $\mathrm{TiO}_{2}$-values suggest some china clay admixture. However, this is not supported by the $\mathrm{Al}_{2} \mathrm{O}_{3}$ content, which is too low for such an ingredient.

The X-ray fluorescence (XRF) bulk body compositions of the Wedgwood samples show comparable silica (73.70-77.29 wt \% $\mathrm{SiO}_{2}$ ) and alumina (18.45-21.74 wt \% $\mathrm{Al}_{2} \mathrm{O}_{3}$ ), but lower potassia (0.92-1.06 wt \% $\mathrm{K}_{2} \mathrm{O}$ ) compared to those of the Staffordshire bodies (SEM-EDS analyses). As outlined before, Josiah Wedgwood I creamware is a mix of two ingredients (ball clay + calcined, ground flint), and his Queen's ware a blend of calcined flint + ball clay + china clay + Cornish stone. China clays have significantly more alumina, and Cornish stones more Alkalis, than Ball clays [25]. This raises the following question: do the analyzed Wedgwood objects belong to the creamware or the Queen's ware category? If the analyzed pieces pertained to the latter, they should have higher $\mathrm{Al}_{2} \mathrm{O}_{3}, \mathrm{Na}_{2} \mathrm{O}$ and $\mathrm{K}_{2} \mathrm{O}$ values than the measured ones, see the discussion of true Queen's ware (faïence feldspathique, [43]) in Section 4.2.1. For this reason and because their chemical composition is similar to that of a Wedgwood cream colored earthenware from 1759 , with, in wt \%, $76.10 \mathrm{SiO}_{2}, 20.45 \mathrm{Al}_{2} \mathrm{O}_{3}, 1.00 \mathrm{Fe}_{2} \mathrm{O}_{3}, 0.75 \mathrm{CaO}, 0.14 \mathrm{MgO}$ and $1.60 \mathrm{Alk}$ [42], one may favor a creamware classification. On the other hand, the microstructural analysis (inclusions type A and B) speaks against this. These objects could therefore document the beginning of the transition from the creamware to the Queen's ware type, with little kaolinite and Cornish stone admixtures.

A particle-induced X-ray emission-particle-induced gamma-ray emission (PIXE-PIGE) analysis revealed deviations from the XRF results [45]. $\mathrm{CaO}$ is significantly higher (3.5 wt \%) and $\mathrm{SO}_{3}$ and $\mathrm{Cl}$ were detected in some amounts (Table 2). One might therefore suspect an admixture of a calcium-containing material (gypsum according to the sulphur?) with some rock salt, but such ingredients were not found in the eight English recipes mentioned by Brongniart and reported in [25] (and Table 6 therein).

The high concentrations of lead (max. $643 \mathrm{ppm} \mathrm{Pb}$ ) in the Wedgwood bodies contrast with the very low level of this element in the raw materials (Table 2, XRF). These do not exceed 10 ppm in carbonates (limestones, dolomites) or 110-240 ppm in clays [49,50]. Such high lead contents may be due to: (1) an addition of Pb glass (frit) during the preparation of the paste; (2) an infiltration of the aqueous suspension containing the crushed glaze during their application on the porous bisque, between the first and the second firing; (3) an infiltration of the molten lead glaze into the bisque during the second firing; (4) an infiltration of $\mathrm{Pb}$ vapors into the ceramic objects during the firings or (5) an insufficient abrasion of the glaze during sample preparation. The fifth hypothesis is unlikely, because great care was taken to completely remove the vitreous film. On the other hand, no fragments of a $\mathrm{Pb}$ frit or a $\mathrm{Pb}$ bearing grog could be observed in the bodies. Therefore, Hypothesis (1) can be 
dismissed too. No argument can be put forward to decide between the remaining hypotheses. The fact that $\mathrm{Pb}$ infiltration has effectively taken place is shown by the profile measurements (see below), but it cannot be decided to what extent the three remaining mechanisms can each be held responsible.
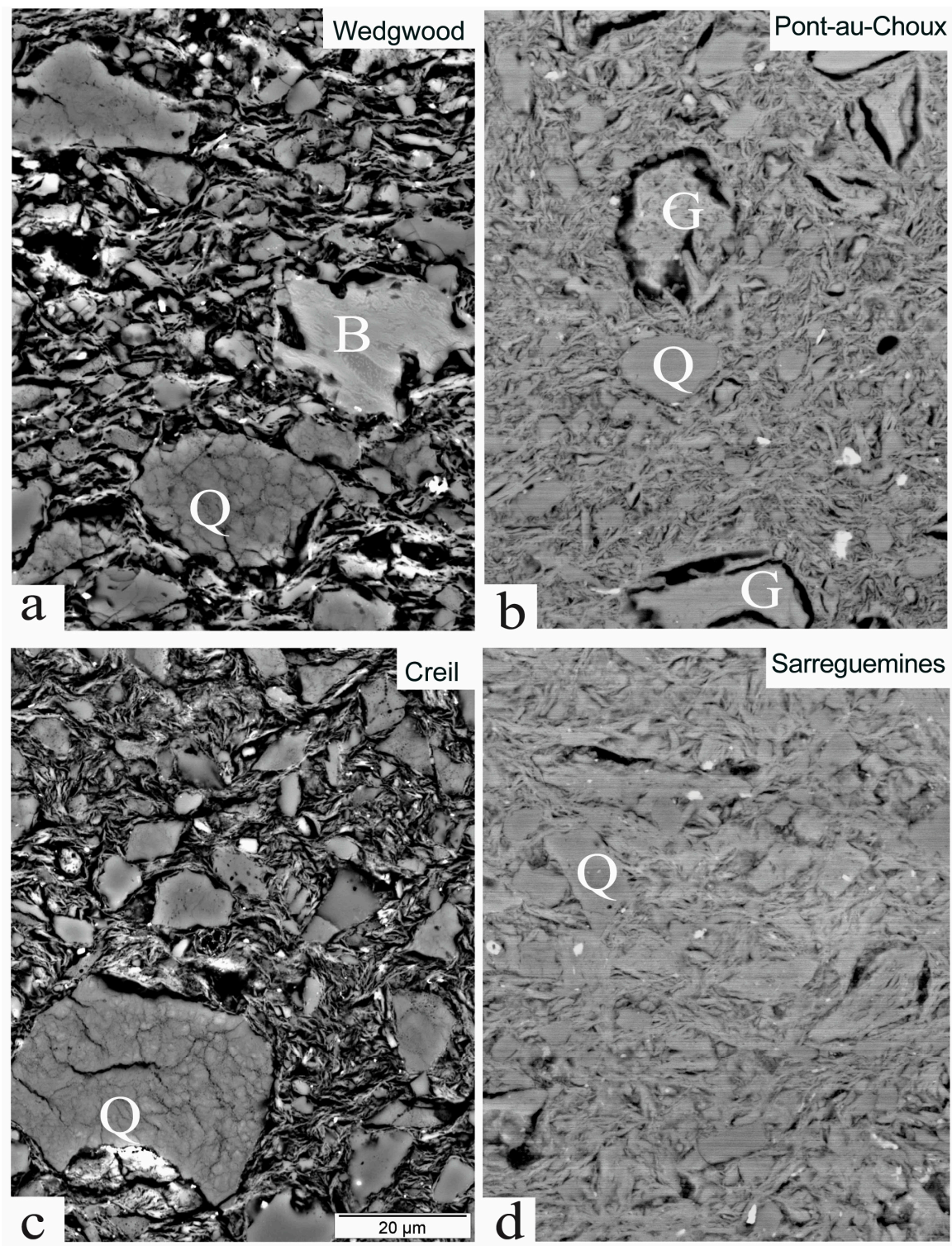

Figure 5. Scanning electron microscope-back scatter detector (SEM-BSE) images of four typical CaO-poor samples from England and France. (a) [25] (Sample Wed-2); (b) [16] (TBL 18); (c) [25] (Creil-2); (d) [16] (TBL 2). B = inclusion type B, G = grog, $Q=$ quartz. Same scale for all.

The PIXE-PIGE analysis revealed surprisingly high $\mathrm{Pb}$ concentrations (Table 2). These are usually related to the presence of $\mathrm{a} \mathrm{Pb}$ frit in the body (see below: French $\mathrm{CaO}$-rich bodies of Lorraine). It would be very surprising that Wedgwood mixed lead frits into his paste. It is therefore more likely that this non-destructive method simultaneously analyzed body together with some lead glaze.

The XRD phase association is characterized by the high temperature phases cristobalite and mullite. Experimental firings of refractory, Ca- and Fe-poor clays reported mullite formation at temperatures above $950{ }^{\circ} \mathrm{C}$ and cristobalite crystallization at temperatures starting at $1050{ }^{\circ} \mathrm{C}[51,52]$. Such high temperatures are in good agreement with the upper limit of ca. $1200-1250{ }^{\circ} \mathrm{C}$ for the first firing stage of creamware or cailloutage bodies [43]. 


\subsubsection{Glazes: Microstructures, Chemical Compositions and Technical Aspects}

The transparent glazes used for the Staffordshire white earthenware are of the high lead type (48.3-57.8 wt \% PbO) containing a considerable amount of silica (35-43.9 wt \% $\left.\mathrm{SiO}_{2}\right)$, small percent of alumina (3.9-6.1 wt \% $\left.\mathrm{Al}_{2} \mathrm{O}_{3}\right)$ and negligible alkali $\left(\mathrm{K}_{2} \mathrm{O}+\mathrm{Na}_{2} \mathrm{O}\right.$ below $\left.1 \mathrm{wt} \%\right)$.

The Wedgwood glazes are typically $50-80 \mu \mathrm{m}$ thick and appear homogenous. There are rare gas bubbles and crystalline phases of (1) subangular and rounded $\mathrm{SiO}_{2}$ grains, interpreted as relict quartz; (2) tiny rectangular $\mathrm{SiO}_{2}$ crystals, often in clusters or surrounding quartz cores, interpreted to be cristobalite because of their crystal habitus. An irregular and undulated intermediate zone with a thickness of ca. $5-20 \mu \mathrm{m}$, consisting of small (less than $2 \mu \mathrm{m}$ ) euhedral, rectangular and zoned crystals rich in alumina, silica, and lead can be observed in the glaze close to the sharp contact with the body. The glaze main components are $\mathrm{PbO}, \mathrm{SiO}_{2}$ and $\mathrm{Al}_{2} \mathrm{O}_{3}$ with minor amounts of $\mathrm{K}_{2} \mathrm{O}, \mathrm{Na}_{2} \mathrm{O}, \mathrm{MgO}, \mathrm{CaO}$, $\mathrm{TiO}_{2}$, and $\mathrm{Fe}_{2} \mathrm{O}_{3}$ (Table 3). Lead infiltration was detected from the glaze/body interface inwards, affecting the outmost $80 \mu \mathrm{m}$ of the bodies ( $5.9 \mathrm{wt} \% \mathrm{PbO}$ in the body close to the contact).

Glazes and ceramic bodies interact during the last firing with complex digestion/diffusion processes [53]. Such processes must have affected the studied samples, as revealed by the important lead diffusion from the glaze into the body. Alongside with this glaze-body contamination, the reverse occurs; i.e., elements diffuse from the ceramic body towards the glaze. Alumina, for instance, migrates in significant concentrations (over $1 \mathrm{wt} \%$ ), as shown by the experimental work of [54], into an alumina-free lead glaze applied on kaolinitic bodies as far as 150-200 $\mu \mathrm{m}$. For the studied samples, such an Al-contamination could have theoretically affected the whole glaze section considering their thicknesses $(50-80 \mu \mathrm{m})$. However, the Al-profile from the contact body/glaze into the glaze revealed a body derived alumina contamination only over a distance of $35 \mu \mathrm{m}$. The high $\mathrm{Al}_{2} \mathrm{O}_{3}$ values measured in the uncontaminated outermost parts must result from the addition of clay or feldspar to the glaze mixture. Unfortunately, the literature does not mention the recipes for Wegdwood's white earthenware glazes.

Table 3. Thicknesses and scanning electron microscope-energy-dispersive X-ray spectroscopy (SEM-EDS) analyses (wt \%) of transparent glazes of English and French $\mathrm{CaO}$ poor white earthenwares.

\begin{tabular}{|c|c|c|c|c|c|}
\hline & Staffordshire & Wedgwood & Pont-aux-Choux & Creil & Sarreguemines \\
\hline Date & 18th century & 1769-1832 & End 18th century & 1797-1832 & ca. 1820 \\
\hline N samples & 5 & 3 & 2 & 1 & 1 \\
\hline Reference & [44] & [25] & [16] & [25] & [16] \\
\hline Thickness $(\mu \mathrm{m})$ & & $50-80$ & $2-260$ & $5-150$ & 25 \\
\hline $\mathrm{Na}_{2} \mathrm{O}$ & $<0.2-0.7$ & $0.1-0.7$ & $1.5-2.4$ & & \\
\hline $\mathrm{MgO}$ & $<0.2-0.4$ & $0.2-1.2$ & $0.1-0.3$ & & 0.2 \\
\hline $\mathrm{Al}_{2} \mathrm{O}_{3}$ & $3.9-6.1$ & $4.5-7.4$ & $3.4-3.5$ & & 7.8 \\
\hline $\mathrm{SiO}_{2}$ & $35.0-43.9$ & $39.2-41.7$ & $32.6-39.1$ & 25.9 & 30.5 \\
\hline $\mathrm{Cl}^{2}$ & & & & 0.5 & \\
\hline $\mathrm{K}_{2} \mathrm{O}$ & $<0.2-0.4$ & $0.0-0.8$ & $1.1-2.2$ & 0.3 & 0.6 \\
\hline $\mathrm{CaO}$ & $0.3-0.8$ & $0.1-0.7$ & $1.4-2.3$ & 0.4 & 0.1 \\
\hline $\mathrm{FeO}, \mathrm{Fe}_{2} \mathrm{O}_{3}$ & $<0.2-0.8$ & $0.3-0.5$ & $0.5-0.6$ & 0.3 & 0.4 \\
\hline $\mathrm{TiO}_{2}$ & $<0.2-0.4$ & 0.2 & 0.1 & & 0.2 \\
\hline $\mathrm{PbO}$ & $48.3-57.8$ & $48.6-52.6$ & $50.2-57.3$ & 72.6 & 60.2 \\
\hline
\end{tabular}

\subsection{French White Earthenware}

As for England, the archaeometric studies of 18th and early 19th French white earthenware are sparse. There is one old Lunéville terre de pipe analysis [42] and another of a bisque from the manufactory Bosch at Luxemburg (1824) [43]. Their iron oxide contents (1.2-2 wt \%) are obviously very high for a white earthenware, which is probably a method-relevant artifact. More recently, seven specimens from two manufactories in and outside Paris (Pont-aux-Choux, $n=5$; Creil, $n=2$ ) as well as 19 objects attributed to six, mostly Lorraine manufactories (Bois d'Épense, Lunéville, Niderviller, Saint-Clément, Sarreguemines and of unknown provenance) were studied [16,25]. Examples of French CaO-poor white earthenware are given in Figure 6. The origin of the five 
Pont-aux-Choux pieces was left open [16]. Meantime, Christian Maire considered the linear detailing between the grains in the rice pattern of the five studied objects [55] to be characteristic of this manufactory. The mean values of two groups (production date 1765-1780, ca. 1820) from the manufactory of Meillonnas can be found in [56] and one single analysis from the small workshop Jussy on the southern shores of lake Geneva in [37].
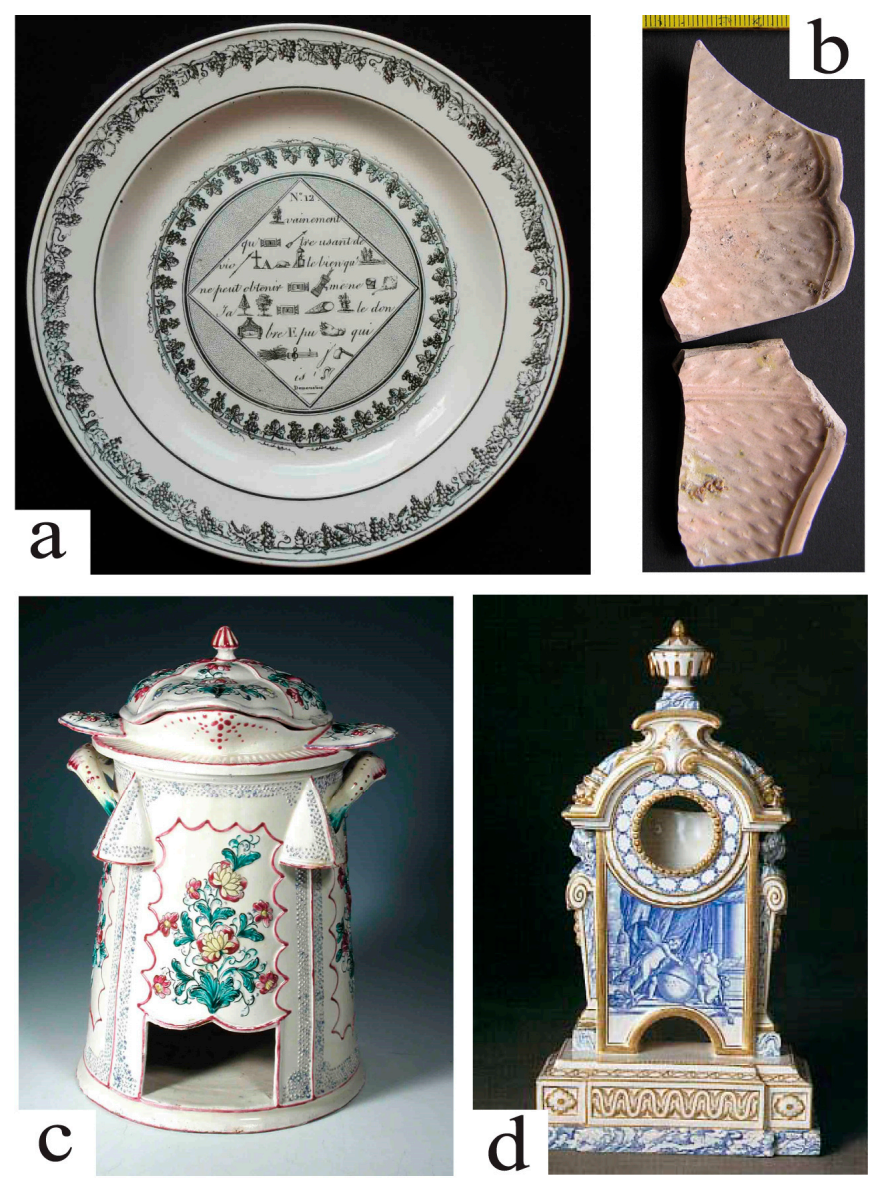

Figure 6. A selection of French objects from collections. (a) Circular plate, transfer-printed in black with a rebus in the center and a floral pattern on the border. Impressed mark "CREIL". Cailloutage (creamware). 1819-1834. Diam.: 21.5 cm. (C) M. Maggetti. Private collection; (b) Two fragments of a saucer, destroyed during the blaze of the Lunéville castle, with a rice grain or barley corn pattern decoration, typical of the Pont-aux-Choux manufactory of Paris, Late 18th century. H: $10.5 \mathrm{~cm}$. @ M. Maggetti. Lunéville castle museum. [16] (An. No. TBL 31); (c) Herbal teapot attributed to Lunéville. Terre de pipe. Late 18th century. H: $23.5 \mathrm{~cm}$. Third-firing embossed decoration. (c) J. Rosen. Private collection. [16] (An. no. TBL 6); (d) Watch stand attributed to St. Clément. Terre de pipe. Ca. $1770 . \mathrm{H}: 39 \mathrm{~cm}$. Third-firing polychrome and gilded decoration. (C) Keramikfreunde der Schweiz. Lunéville castle museum. [16] (An. No. TBL 21).

\subsubsection{Body: Microstructures, Chemical Compositions and Technical Aspects}

The five unmarked samples (from a museum collection destroyed by a fire) with a rice-grain molded decoration typical for the Pont-aux-Choux factory (Figure 6b) exhibit a grog rich body (Figure 5b). The quartzes were already present in the clay, as exemplified by their rounded shapes. These samples differ from the Wedgwood objects by a very high alumina content (Figure 7a). Their microstructure is in good agreement with the paste recipe of Pont-aux-Choux; i.e., a mix of local Moret clay with its calcined counterparts in a ratio 66:33, as reported by Hellot (quoted by [13]) (p. 60). Moret clay is a variant of the widespread Montereau clay [25] and has been characterized in 1778 as " .. . little sandy, very binding \& very refractory. The best and purest of all ... " is from a great dig on 
the way to the mountain of Moret. A pretty pottery of white earthenware of the English type is made in Montereau, and even more in Paris, at the manufactory of Pont-au-choux" [57]. Grog and bodies are as expected $\mathrm{CaO}$-poor ( $<1 \mathrm{wt} \%)$, but richer in $\mathrm{Al}_{2} \mathrm{O}_{3}$ as the published chemical analyses of Montereau clays (max. $31 \mathrm{wt} \% \mathrm{Al}_{2} \mathrm{O}_{3}$ [25]), see [16]. The chemical composition is clearly different from that of the Wedgwood tableware (Table 2). The high alumina and low silica match the microscopic appearance. However, the Sr values are surprisingly high and not yet explained.

Both Creil specimens (consumption site, marked pieces) differ chemically (Table 2) and microstructurally from the Pont-aux-Choux products. They are like those of the Wedgwood ware, but without grog inclusions (Figure 5c). This fits in well with this kind of body, named cailloutage, where calcined and crushed flint ("cailloux") were admixed to a non calcareous Montereau clay in the typical English creamware tradition [20,23]. Their elemental composition, however, is very distinct from the three Wedgwood samples, as they show considerably lower amounts of $\mathrm{TiO}_{2}, \mathrm{~K}_{2} \mathrm{O}, \mathrm{Ba}, \mathrm{Cu}$, $\mathrm{Rb}, \mathrm{Zn}$, and Zr, and higher contents of Sr and Y (Table 2). With the help of the Y-Zr binary diagram, they can well be distinguished from the Wedgwood ware (Figure $7 \mathrm{~b}$ ).
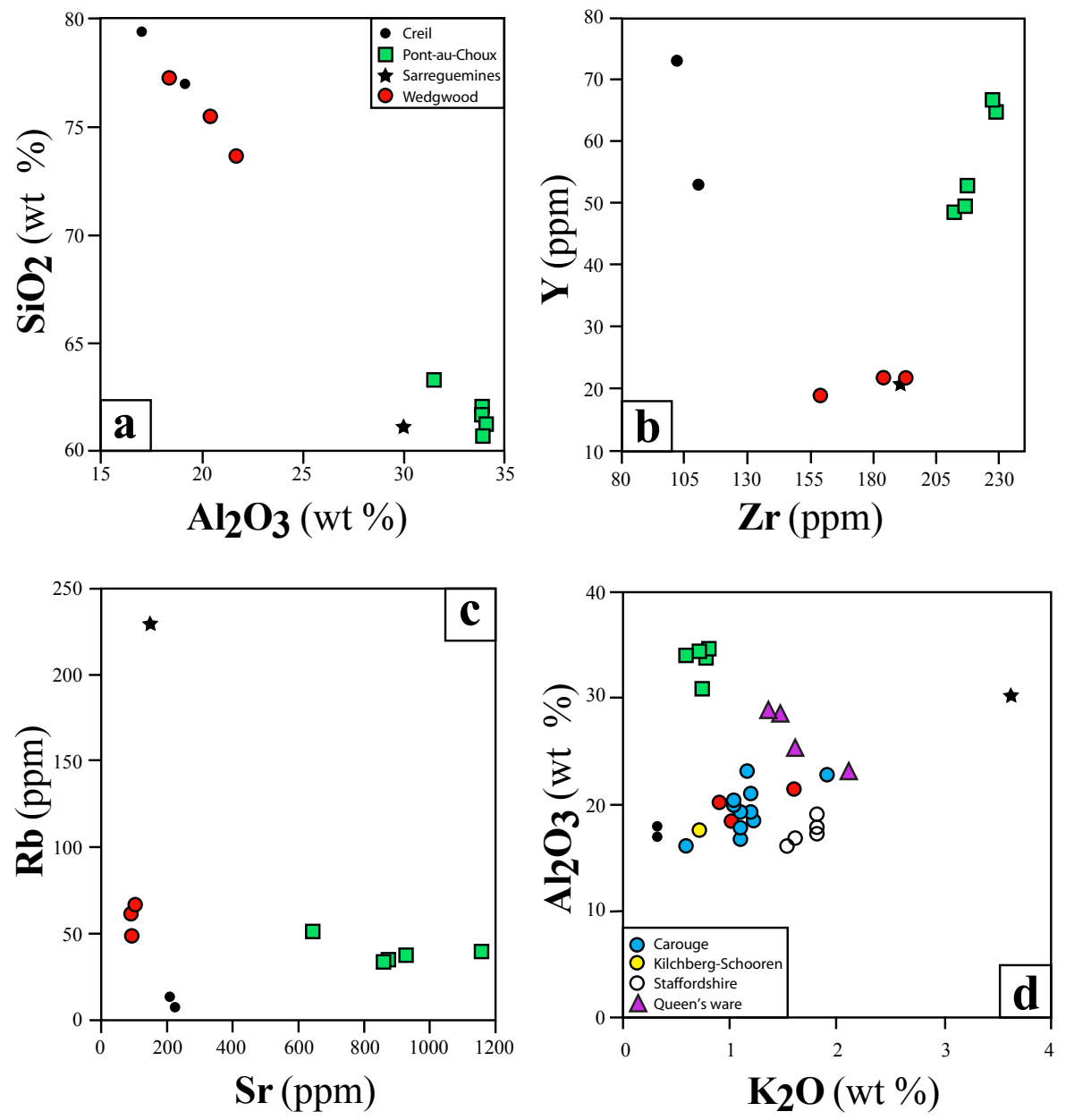

Figure 7. Body (bulk) compositions (XRF analyses) for the English and French CaO-poor samples displayed on three selected binary diagrams: (a) $\mathrm{SiO}_{2}-\mathrm{Al}_{2} \mathrm{O}_{3}$, (b) $\mathrm{Y}-\mathrm{Zr}$ and (c) $\mathrm{Rb}-\mathrm{Sr}$ plot from [16]. (d) $\mathrm{Al}_{2} \mathrm{O}_{3}-\mathrm{K}_{2} \mathrm{O}$ diagram with the samples as in Figure $7 \mathrm{a}-\mathrm{c}$, completed with more European CaO-poor white earthenwares from Carouge [37], Kilchberg-Schooren [58], Staffordshire [44] and French \& Belgian Queen's ware types (faïence feldspathique) [43].

The stamped bowl from Sarreguemines (private collection) has a rare pink luster Burgos, characteristic of this manufactory in the 1820's. Its microstructure differs significantly from that of the 
objects from Creil and the Wedgwood manufactories and is similar to that of Pont-aux-Choux, although no grog could be observed (Figure $5 \mathrm{~d}$ ). Their chemical composition differs from that of Pont-aux-Choux (Table 2), and both products can easily be differentiated as shown in Figure 7. $\mathrm{Na}_{2} \mathrm{O}$ and $\mathrm{K}_{2} \mathrm{O}$ are much higher in the Sarreguemines sample compared to the Pont-aux-Choux specimens. The raw clays were therefore different in both factories.

The CaO-rich unmarked bodies (museum and private collections, Table 4) from Lorraine and the neighboring Bois d'Épense manufactory are composed of (Figure 8): (1) angular $\mathrm{SiO}_{2}$ fragments (=quartz) with diameters not exceeding $340 \mu \mathrm{m}$. As no internal cracks and sub-domains typical for calcined flint grains can be observed, it is assumed that they most probably correspond to calcined sand or quartz pebbles. This contradicts the currently known recipes, which list only flint, but no quartz pebbles or quartz sand [16]; (2) roundish to angular lead-silica frits; (3) CaO-rich particles and more or less circular pores corresponding to primary particles rich in $\mathrm{CaO}$ - that is, carbonate or portlandite $\mathrm{Ca}(\mathrm{OH})_{2}$ - having reacted with the clay paste during the firing; and (4) a fine-grained matrix [16,25]. Angular potassium feldspar and grog grains can also be found in some bodies.

Three frit types can be defined according to their microstructure and chemical composition: (1) cassiterite-bearing $\mathrm{PbO}-\mathrm{SiO}_{2}$ frit (rare), Figure 8a; (2) low-Ca PbO-SiO 2 frit (Figures 8b and 9); and (3) high- $\mathrm{Ca} \mathrm{PbO}-\mathrm{SiO}_{2}$ frit. Two $\mathrm{SiO}_{2}$-polymorphs can be observed in the cassiterite-free frits: rounded individual grains or cores of $\mathrm{SiO}_{2}$-clusters, interpreted to be relic quartzes, and idiomorphic laths, probably cristobalite in view of the crystal habitus, either as clustered individuals or surrounding quartz cores. The relative amounts of glassy and crystalline phase(s) in the frit particles are highly variable. The contact with the surrounding matrix is well defined and sharp. With few exceptions, no $\mathrm{Pb}$ diffusion from the frits into the surrounding ceramic matrix could be measure. The overall chemical composition of the matrix; i.e., the former clay-is close to that of kaolinitic-illitic clays. According to modal analyses, the amount of former clay (matrix) in these artificial bodies shows less variation (57-70 vol \%) than the quartz (6-27 vol \%), the CaO-rich area (0.6-8.5 vol \%) and the frit contents (3-8 vol \%).

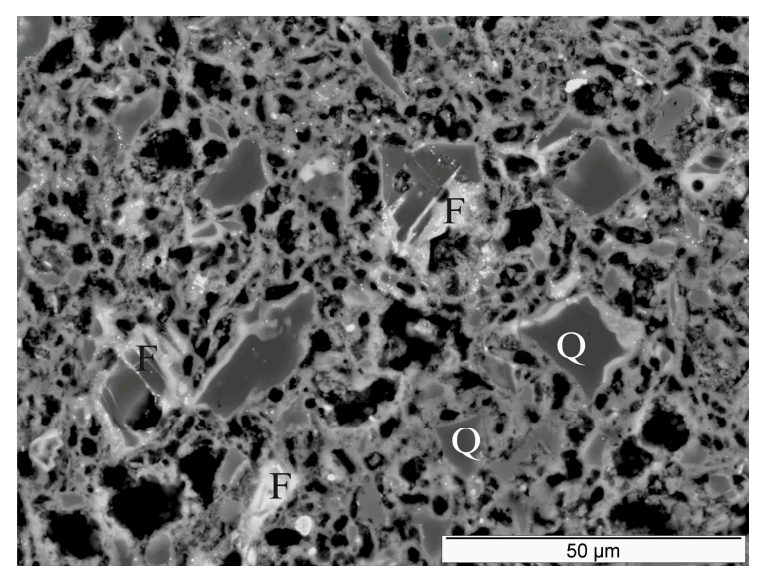

(a)

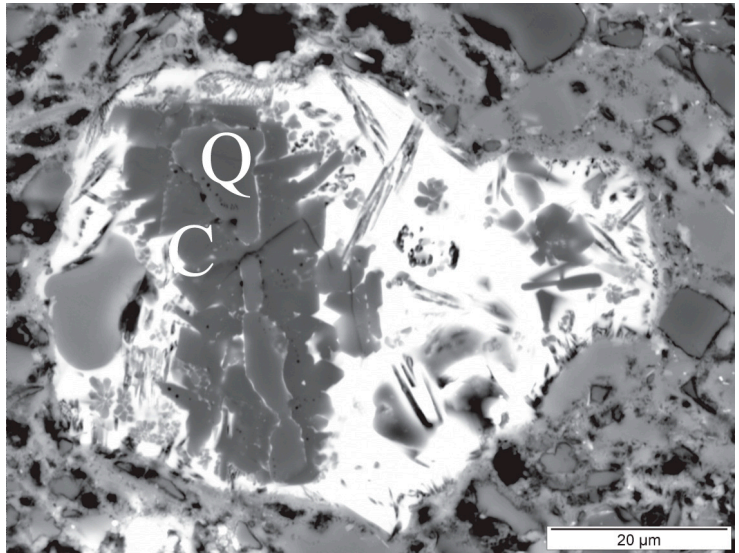

(b)

Figure 8. SEM-BSE images. (a) CaO-rich broth bowl with handle from Saint-Clément. [16] (An. No. TBL 19) showing angular fragments of quartz (Q), either as isolated grains or embedded in glassy patches (white). The latter case corresponds to a cassiterite-bearing lead alkali frit (F); (b) Lead frit with relic quartz $(\mathrm{Q})$ core, surrounded by presumably cristobalite $(\mathrm{C})$ laths in a Pb-rich glass (white). Basal fragment with impressed mark "NIDERVILLER". [25] (An. No. Nider-1). 
Table 4. Chemical compositions (Min.-Max.) of French CaO-rich white earthenware. Oxides in wt \%, elements in ppm.

\begin{tabular}{|c|c|c|c|c|c|c|c|c|}
\hline & Bois d'Epense & Lunéville & Mei & inas & Niderviller & Saint-Clément & Sarreguemines & Jussy \\
\hline Date & End 18th century & ca. 1780 -end 18 th century & $1765-1780$ & ca. 1820 & ca. $1770,1793-1802$ & $1755-1760$, ca. 1770 , end 18 th century & ca. 1805 & 1824-1839 \\
\hline $\mathrm{N}$ analyses & 1 & 5 & 9 & 2 & 2 & 9 & 1 & 1 \\
\hline Method & XRF & XRF & XRF & XRF & XRF & XRF & SEM-EDS & XRF \\
\hline Reference & [16] & [16] & [55] & [55] & {$[16,25]$} & [16] & [16] & [37] \\
\hline $\mathrm{SiO}_{2}$ & 66.95 & $68.47-70.07$ & $67.45-74.86$ & $60.17-61.19$ & $64.59-66.87$ & $57.15-63.72$ & 73.0 & 57.06 \\
\hline $\mathrm{TiO}_{2}$ & 0.61 & $0.40-0.54$ & $0.48-0.57$ & $0.56-0.57$ & $0.45-0.65$ & $0.60-0.83$ & 0.7 & 0.76 \\
\hline $\mathrm{Al}_{2} \mathrm{O}_{3}$ & 14.39 & $9.14-10.99$ & $10.53-13.35$ & $15.00-15.55$ & $12.94-16.44$ & $15.39-19.33$ & 12.2 & 14.34 \\
\hline $\mathrm{Fe}_{2} \mathrm{O}_{3}$ & 0.82 & $0.45-0.56$ & $1.08-1.29$ & $1.36-1.62$ & $0.90-0.93$ & $0.60-0.82$ & 0.7 & 0.77 \\
\hline $\mathrm{MnO}$ & 0.02 & $0.01-0.02$ & $0.01-0.02$ & $0.01-0.04$ & $0.01-0.02$ & $0.01-0.02$ & & \\
\hline $\mathrm{MgO}$ & 0.36 & $0.55-0.81$ & $0.63-0.84$ & $6.23-7.61$ & $0.57-0.60$ & $0.36-0.46$ & 0.5 & 9.18 \\
\hline $\mathrm{CaO}$ & 13.64 & $12.12-14.56$ & 7.43-14.95 & $12.90-13.65$ & $10.49-16.81$ & $14.56-17.03$ & 10.7 & 13.31 \\
\hline $\mathrm{Na}_{2} \mathrm{O}$ & 1.39 & $2.72-2.32$ & $0.42-1.70$ & $0.06-0.10$ & $1.06-2.13$ & $0.34-1.39$ & 0.8 & 0.39 \\
\hline $\mathrm{K}_{2} \mathrm{O}$ & 0.61 & $1.26-2.01$ & $1.21-2.03$ & $1.28-1.49$ & $0.91-1.58$ & $1.69-1.95$ & 1.4 & 1.89 \\
\hline $\mathrm{P}_{2} \mathrm{O}_{5}$ & 0.10 & $0.11-0.26$ & $0.14-0.22$ & $0.16-0.26$ & $0.14-0.15$ & $0.05-0.10$ & & 0.04 \\
\hline $\mathrm{Ba}$ & 108 & 200-255 & 153-189 & $189-259$ & $302-420$ & $226-432$ & & 277 \\
\hline $\mathrm{Cr}$ & 61 & $57-91$ & $14-62$ & $70-71$ & $69-123$ & $88-123$ & & 84 \\
\hline $\mathrm{Cu}$ & 46 & $17-71$ & & & $27-32$ & $16-116$ & & 28 \\
\hline $\mathrm{Nb}$ & 14 & $11-12$ & & & $11-12$ & $16-19$ & & 16 \\
\hline $\mathrm{Ni}$ & 17 & $17-26$ & $15-25$ & $24-31$ & $26-47$ & $29-117$ & & 35 \\
\hline $\mathrm{Pb}$ & 11,840 & $2525-12,964$ & & & $3657-7424$ & $11,681-27,880$ & & 12,736 \\
\hline $\mathrm{Rb}$ & 9 & $44-120$ & 53-119 & $72-77$ & $58-74$ & $11-91$ & & 71 \\
\hline $\mathrm{Sr}$ & 380 & $246-327$ & $220-367$ & $94-118$ & 294-389 & $262-341$ & & 86 \\
\hline Y & 45 & $16-26$ & & & $18-36$ & $34-57$ & & 42 \\
\hline $\mathrm{Zn}$ & 90 & $5-14$ & $1-21$ & $10-25$ & $27-29$ & & & 61 \\
\hline $\mathrm{Zr}$ & 182 & $128-165$ & $263-319$ & $257-265$ & $126-162$ & $183-256$ & & 185 \\
\hline
\end{tabular}


Stylistic and Cluster analyses attribute 17 tableware samples to five manufactories (Bois d'Épense, Lunéville, Niderviller, Saint-Clément, Sarreguemines) while two samples could not be assigned to any manufactory. Considering the products of Sarreguemines, it reveals a change in the recipe between 1805 and ca. 1820, with a transition from CaO-rich to a CaO-poor body (Tables 3 and 4). Further analyses of well-dated objects could define this change even more precisely.

The faïence manufactory Meillonnas also produced CaO-rich dishes in both 18th and 19th centuries (Table 4). The studied samples are from excavations on the production site and include unmarked bisque and glazed fragments [56]. The largest chemical difference is found in the $\mathrm{MgO}$ concentration, which is below $1 \mathrm{wt} \%$ in the older group, dated 1765-1780, but reaches $6-7 \mathrm{wt} \%$ in the younger group (Early 19th century). From the 18th to the 19th century, therefore, a significant change in the recipe must have taken place. Although there are no SEM analyses of these objects, it can be assumed that dolomitic raw materials were used in the younger group. Their synthetic bodies are made with White of Bresse (a whitefiring local refractory clay), to which is added, in a proportion of one fifth, a blend composed of half limestone and half imported dolomite. This results in the following \%: 80 White of Bresse +10 lime +10 dolomite, whereas the older group is made of 90 White of Bresse +10 lime [55]. A detailed discussion of this specific dolomitic ingredient will be given in Section 4.3.
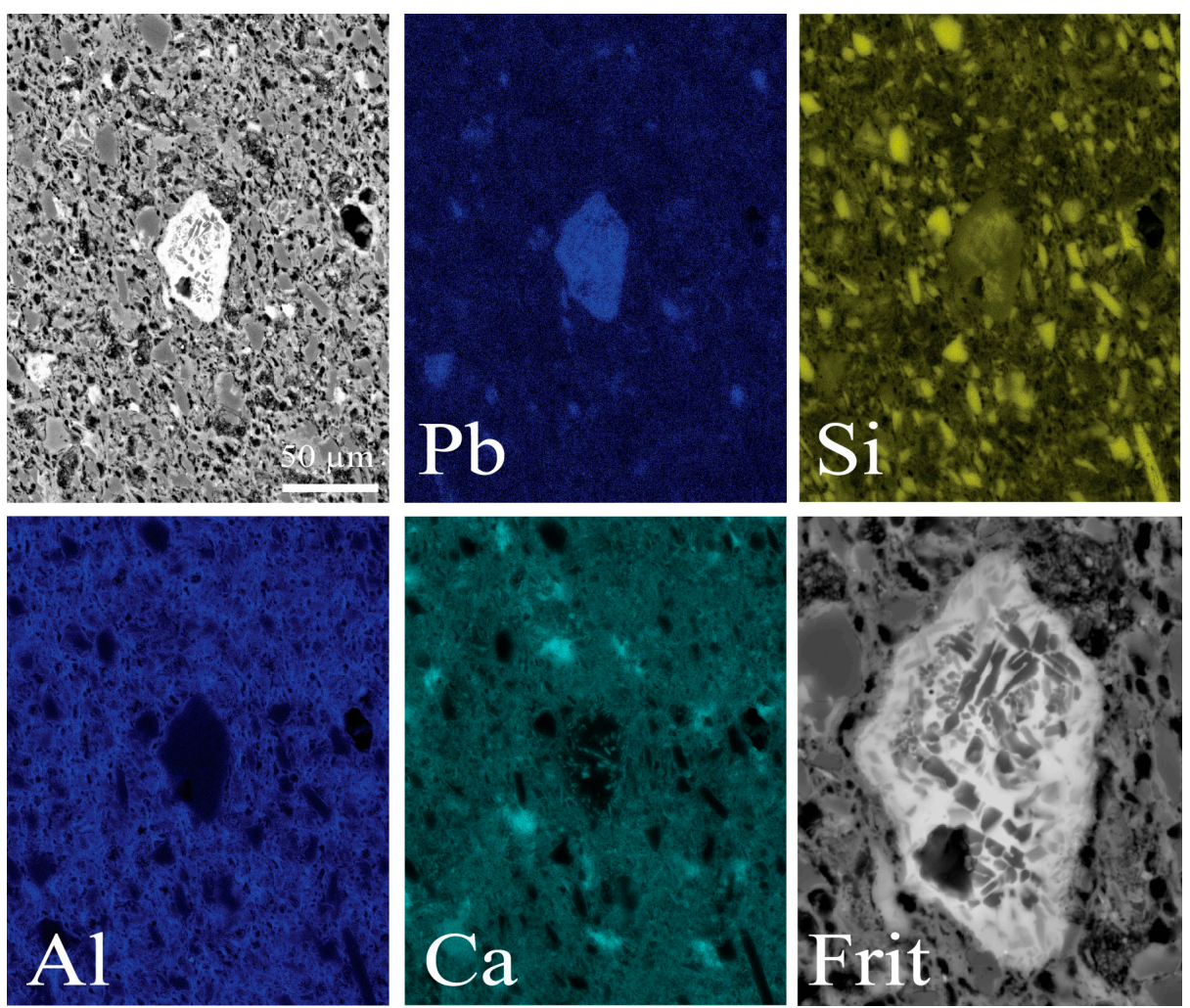

Figure 9. SEM-BSE image of a CaO-rich watch stand (Figure 6d) from Saint-Clément, [16] (An. No. TBL 21), showing tiny angular fragments of crushed quartz and angular to subrounded fragments of coarser $\mathrm{PbO}-\mathrm{SiO}_{2}$-frits, as well as the corresponding elemental maps of $\mathrm{Pb}, \mathrm{Si}, \mathrm{Al}$, and $\mathrm{Ca}$. The close up of the frit reveals neoformations (grey to black needles and grains) of presumed cristobalite and wollastonite crystals in a glassy $\mathrm{Pb}$-rich matrix (white).

In the second quarter of the 19th century, at about the same time as Meillonnas' group 2, the small Jussy manufactory, located not far from it on the southern shore of Lake Geneva, also produced a white earthenware rich in $\mathrm{MgO}$ (one marked piece from a private collection analyzed, Table 4). Here too, dolomitic ingredients must have been used. This is not surprising as the factory bought the recipe 
from the Swiss manufactory Robillard in Nyon situated on the opposite northern shore of the lake, see Section 4.3.

The XRD-determined phase association of the CaO-poor objects (Creil, Pont-aux-Choux, Sarreguemines) consists of cristobalite, mullite, and quartz. This shows, based on experimental firings $[51,52]$ that temperatures above $1050{ }^{\circ} \mathrm{C}$ have been reached. Such high temperatures are in good agreement with the upper limit of ca. $1200-1250{ }^{\circ} \mathrm{C}$ for the first firing of these bodies (Table 1). The XRD phase associations of the $\mathrm{CaO}$-rich white earthenwares are compatible with maximum firing temperatures of $800-900$ respectively $900-1050{ }^{\circ} \mathrm{C}$ [16]. Such temperatures fall in the usual range of the French faïence kilns of the 18th century [59].

\subsubsection{Glazes: Microstructures, Chemical Compositions and Technical Aspects}

The glazes of two Pont-aux-Choux samples are macroscopically transparent, without any inclusions and consist mainly of $\mathrm{SiO}_{2}$ (33-39 wt \%) and $\mathrm{PbO}(50-57 \mathrm{wt} \%)$, Table 3. No reaction zones could be observed between the glazes and the bodies. Both Creil transparent and inclusion free glazes show severe burial leaching effects which made a chemical analysis very difficult. The result, $\mathrm{SiO}_{2} 26 \mathrm{wt} \%$ and $\mathrm{PbO} 73 \mathrm{wt} \%$, does evidently not correspond to the original composition and must be checked with objects from collections. There are no glaze-body reaction zones. Glazes on CaO-rich Lorraine bodies are macroscopically either transparent or opaque white, the latter containing many tiny tin oxide crystals (cassiterites $\mathrm{SnO}_{2}$ ) and lack any reaction zone (Figure 10). Cassiterite-free glazes are much thinner than the other type. Regarding the conspicuous quartz grains in the glaze, see the discussion below. A glaze analysis of a single Niderviller white earthenware does not differ much from the Staffordshire and Wedgwood glazes if both main components are taken into account $\left(\mathrm{SiO}_{2} 40 \mathrm{wt} \%\right.$ and $\left.\mathrm{PbO} 51 \mathrm{wt} \%\right)$. However, they have a higher Alkali content (2-5 wt \%) [25]. A much younger sample from Niderviller and five from Saint-Clément have tin oxide opacified glazes, see Figure 10b [16]. Their composition is quite similar (Table 5), with $\mathrm{SnO}_{2}$ varying from 7 to $10 \mathrm{wt} \%$, corresponding to traditional faïence glazes [6,59]. The use of an expensive ingredient such as tin is puzzling. This procedure could have been motivated by the fact that the transparent glaze was soft, easily corroded, and subject to crazing [23]. A rather hard tin-glaze, well adapted to a CaO-rich body such as that of traditional faïence and the new white earthenware- the coefficient of thermal expansion of both bodies matching those of lead alkali glazes $[60,61]$ — made it possible to avoid these drawbacks.

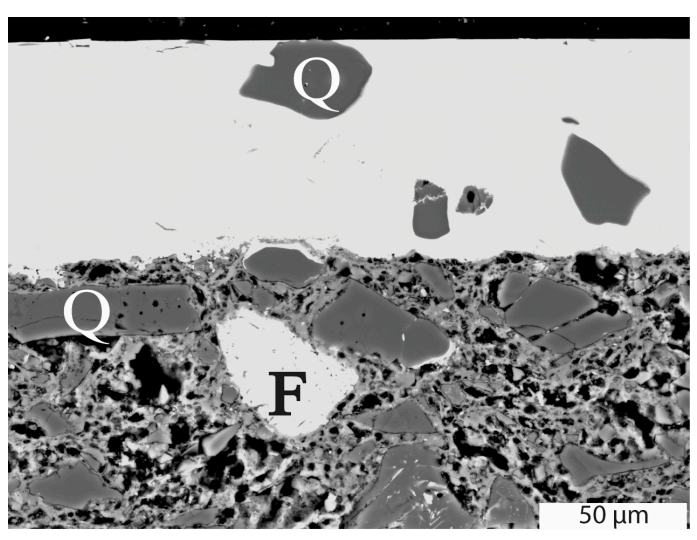

(a)

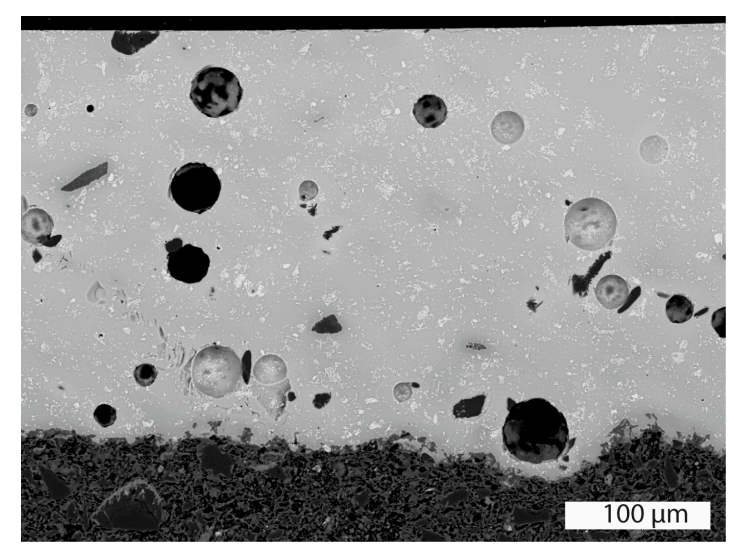

(b)

Figure 10. SEM-BSE image of sections through the glaze (top) and the body (below) of French CaO-rich white earthenwares from Lorraine. (a) Cassiterite-free $\mathrm{SiO}_{2}-\mathrm{PbO}$ glaze with few corroded, former angular quartz inclusions of the same granulometry as those in the body. The body is rich in angular quartz (Q)- and lead frit (F)-fragments. No reaction zone between the glaze and the body. Niderviller, Sample BER 16 [25]; (b) Cassiterite-bearing lead glaze with many gas bubbles and small crystalline inclusions of quartz and feldspar. No reaction zone between the glaze and the body. Saint-Clément, TBL 21 [16]. 
Table 5. Thicknesses and SEM-EDS analyses (wt \%) of opaque (white) and transparent glazes of French $\mathrm{CaO}$ rich white earthenware.

\begin{tabular}{cccc}
\hline & \multicolumn{2}{c}{ Niderviller } & Saint-Clément \\
\hline Date & ca. 1770 & $1793-1832$ & 1755-ca. 1770/18th century \\
N samples & 1 & 1 & 5 \\
Reference & {$[16]$} & {$[25]$} & {$[16]$} \\
Thickness $(\mu \mathrm{m})$ & $100-140$ & 80 & $300-500$ \\
$\mathrm{Na}_{2} \mathrm{O}$ & 1.8 & 0.5 & $1.2-2.6$ \\
$\mathrm{MgO}$ & 0.2 & 0.9 & $0.1-0.3$ \\
$\mathrm{Al}_{2} \mathrm{O}_{3}$ & 4.7 & 5.9 & $4.2-5.9$ \\
$\mathrm{SiO}_{2}$ & 48 & 40.4 & $45.2-47.6$ \\
$\mathrm{Cl}$ & & & \\
$\mathrm{K}_{2} \mathrm{O}$ & 2.3 & 0.3 & $2.0-3.2$ \\
$\mathrm{SnO}_{2}$ & 8.2 & & $7.2-10.0$ \\
$\mathrm{CaO}$ & 1 & 0.3 & $0.4-1.2$ \\
$\mathrm{TiO}_{2}$ & & 0.1 & 0.2 \\
$\mathrm{Fe}_{2} \mathrm{O}_{3}$ & 0.6 & 0.4 & $0.1-0.5$ \\
$\mathrm{PbO}$ & 32.4 & 51.2 & $29.9-35.3$ \\
\hline
\end{tabular}

The composition of Meillonnas' glazes is not known, but a recipe for the younger group from 1817 is reported [56]: 200 p. (pounds) of calcined lead +12 p. tin from Malacca +160 p. sand from Nevers +60 p. gravel ash +24 p. soda from Alicante +28 p. sea salt +7 ounces of azur. All these, well mixed materials were put in the kiln, in the shape of a sugar loaf coated with wet sand, on a ceramic container. After fusion and cooling, a beautiful "crystal" is obtained that will be removed from the kiln with subsequent cleaning, pounding, sieving, and grinding.

\subsection{Swiss White Earthenware}

Between 1766 and 1803, white earthenware started to be produced in at least eight manufactories in Switzerland [19], see Figures 11-13. In this country too, the archaeometric studies are only at the beginning, because very few pieces were analyzed and not from all manufactories: one unmarked bisque fragment from the production site in Fribourg [62,63], one marked Matzendorf fragment from archaeological excavations on a consumption site [19], 29 bisques and glazed fragments (only three stamped) found in archaeological excavations on the production site of Kilchberg-Schooren $[64,65]$ and 39 marked objects (14 from consumption sites; i.e., archaeological excavations and 25 from museum and private collections) from the manufactories in Carouge and Nyon [37].

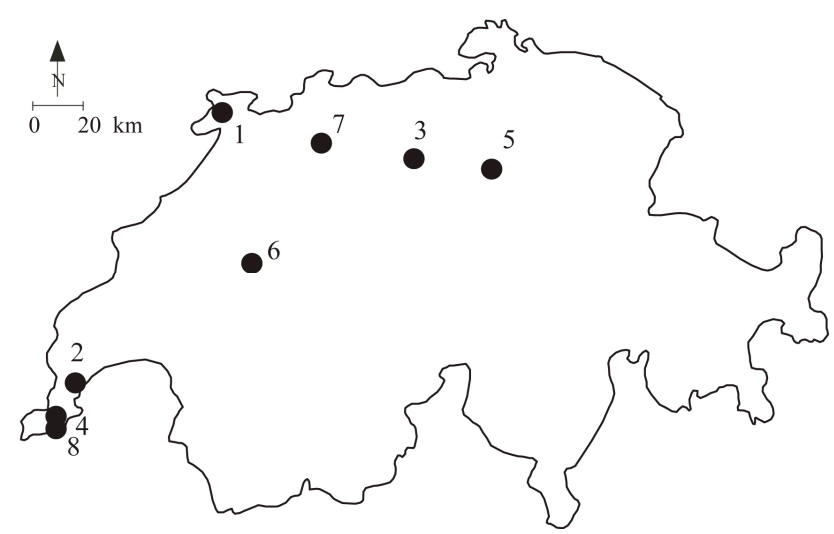

Figure 11. Map of Switzerland with the location of eight white earthenware manufactories: 1 Cornol (production start 1766), 2 Nyon (1790), 3 Lenzburg (1790), 4 Les Pâquis, Geneva (1791), 5 Kilchberg-Schooren, South of Zurich (1792), 6 Fribourg/Freiburg (1794), 7 Matzendorf (1798) and 8 Carouge (1803). 

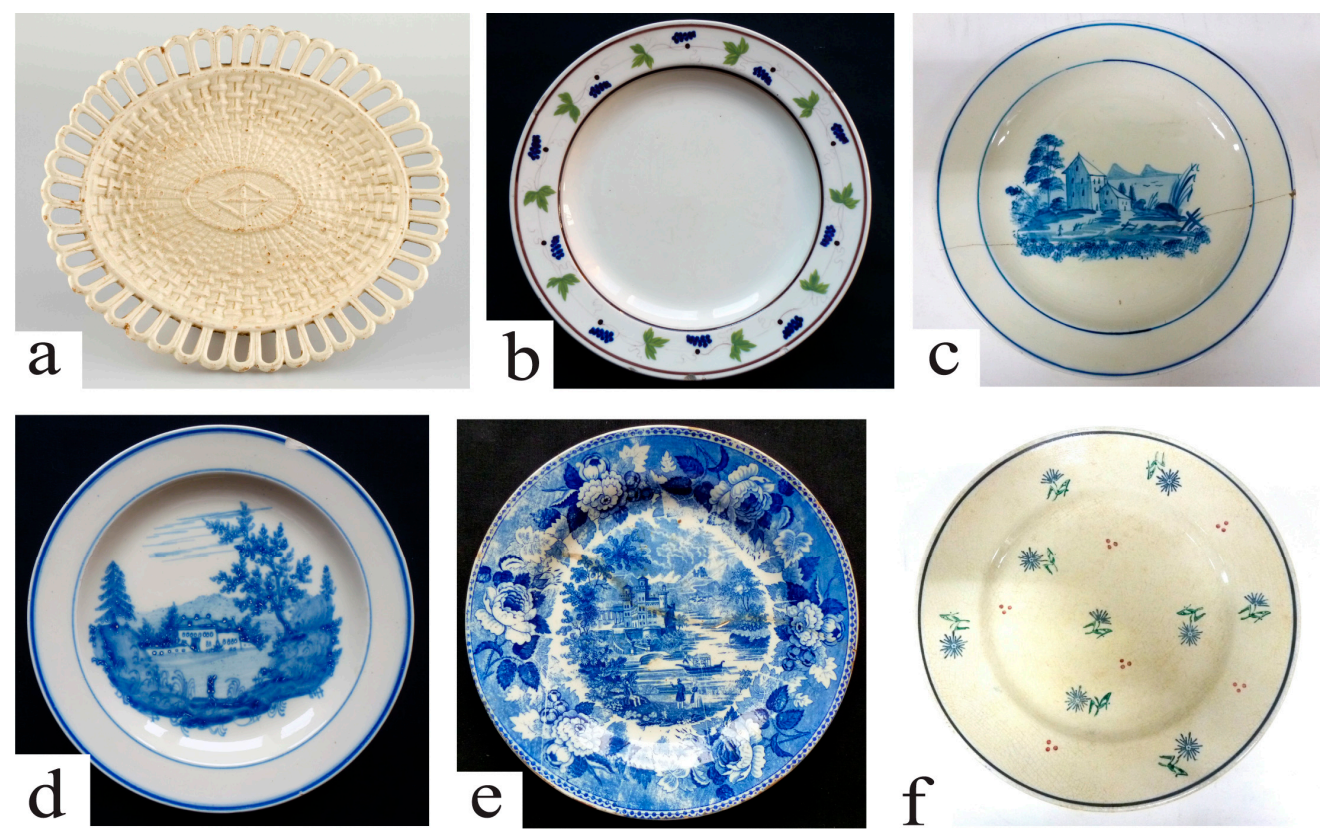

Figure 12. A selection of Swiss $\mathrm{CaO}-\& \mathrm{MgO}$-rich objects from collections. (a) Oval stand of a dessert basket. Impressed marks "MAZENDORF" and the number "3". Matzendorf, ca. 1800. L.: $25.5 \mathrm{~cm}$. Keramikmuseum Matzendorf (SFM 17). (C) R. Blaettler; (b) Plate. Impressed mark “DORTU, VERET et C". Jacob Dortu manufactory, Carouge, 1813-1819. D: $21.3 \mathrm{~cm}$. Polychrome underglaze painting. Private collection. [37] (An. No. NYO 3). (C) M. Maggetti; (c) Plate. Impressed mark “NYON". Delafléchère manufactory, Nyon, 1832/33-1845. D: $20.4 \mathrm{~cm}$. Blue underglaze painting. Musée historique et des porcelaines, Nyon (MH/FA/001808). [37] (an. no. NYO 7). (c M. Maggetti; (d) Plate. Impressed mark "BAYLON". Baylon manufactory, Carouge, ca. 1845. D: $21.5 \mathrm{~cm}$. Blue underglaze painting. Musée de Carouge (CE 2309). [37] (an. no. CAR 5). (C) M. Maggetti; (e) Plate. Impressed mark "BAYLON". Baylon manufactory, Carouge, 1831-1850. D: $21.0 \mathrm{~cm}$. Blue transfer-printing. Musée de Carouge. [25] (an. no. CAR 19). (c) M. Maggetti; (f) Plate. Blue underglaze paint mark "MN" with central fish and "NYON" around. Terribilini manufactory "des poteries fines", Nyon, 1920-1930. D: $19.5 \mathrm{~cm}$. Polychrome floral underglaze painting. Musée historique et des porcelaines, Nyon (MH/FA/010023). [37] (an. no. NYO 10). (C M. Maggetti.
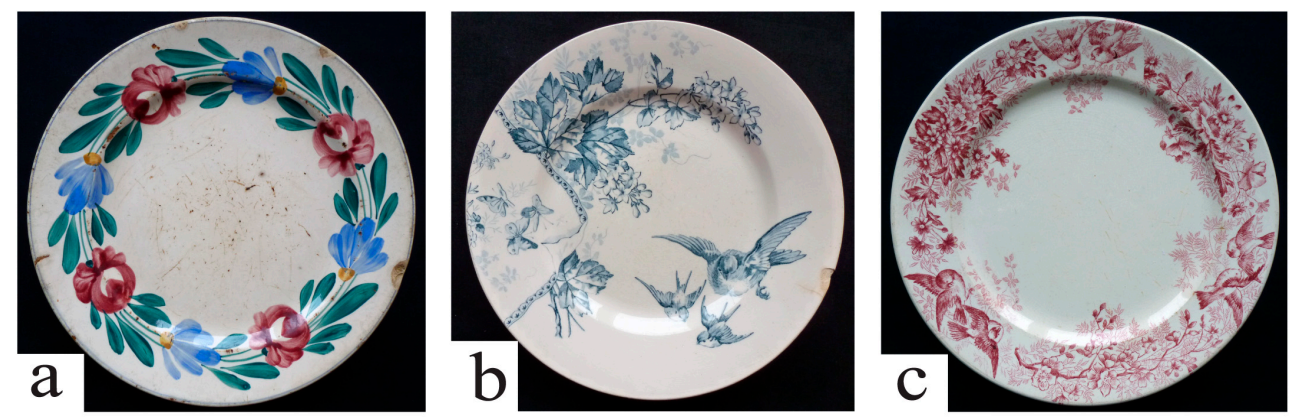

Figure 13. A selection of Swiss CaO-poor objects from the Musée de Carouge. (a) Plate. Impressed marks "IVO" and the number " 5 ". Picolas \& Neuenschwander manufactory, Carouge, 1880. D.: $23.8 \mathrm{~cm}$. Polychrome underglaze painting. Musée de Carouge [37] (an. no. CAR 13); (b) Plate. Impressed marks "IVOIRE", "D \& C" and the number "5". Charles Degrange \& Cie. manufactory, Carouge, 1885-1903. D.: $22.8 \mathrm{~cm}$. Blue underglaze transfer-printing. [37] (an. no. CAR 15); (c) Plate. Impressed marks "IVOIRE" and the number " 5 ". Overglaze stamp "AUBEPINE/C.C." Clément Coppier manufactory, Carouge, 1010-1928. D.: 23.8 cm. Rose underglaze transfer-printing. [37] (an. no. CAR 14). ( ) M. Maggetti. 


\subsubsection{Body: Microstructures, Chemical Compositions and Technical Aspects}

The bodies from the eastern manufactories (Fribourg, Matzendorf, Kilchberg-Schooren) of Switzerland differ significantly from those from the western ones (Carouge, Nyon).

Bodies from Fribourg (production period 1776-1810), Matzendorf (1800-1805) and from two older production periods of Kilchberg-Schooren (ca. 1800-1810, 1st quarter of 19th century [65]) have a CaO-content of 7 to $13 \mathrm{wt} \%$, whereas the youngest Kilchberg-Schooren type pertains to the CaO-poor ware (Table 6). Obviously, around 1825/1830, the paste recipe of this manufactory changed from $\mathrm{CaO}$-rich to -poor.

Both CaO-rich Kilchberg-Schooren types usually plot in many binary correlation diagrams into two chemically distinct groups (Figure 14).
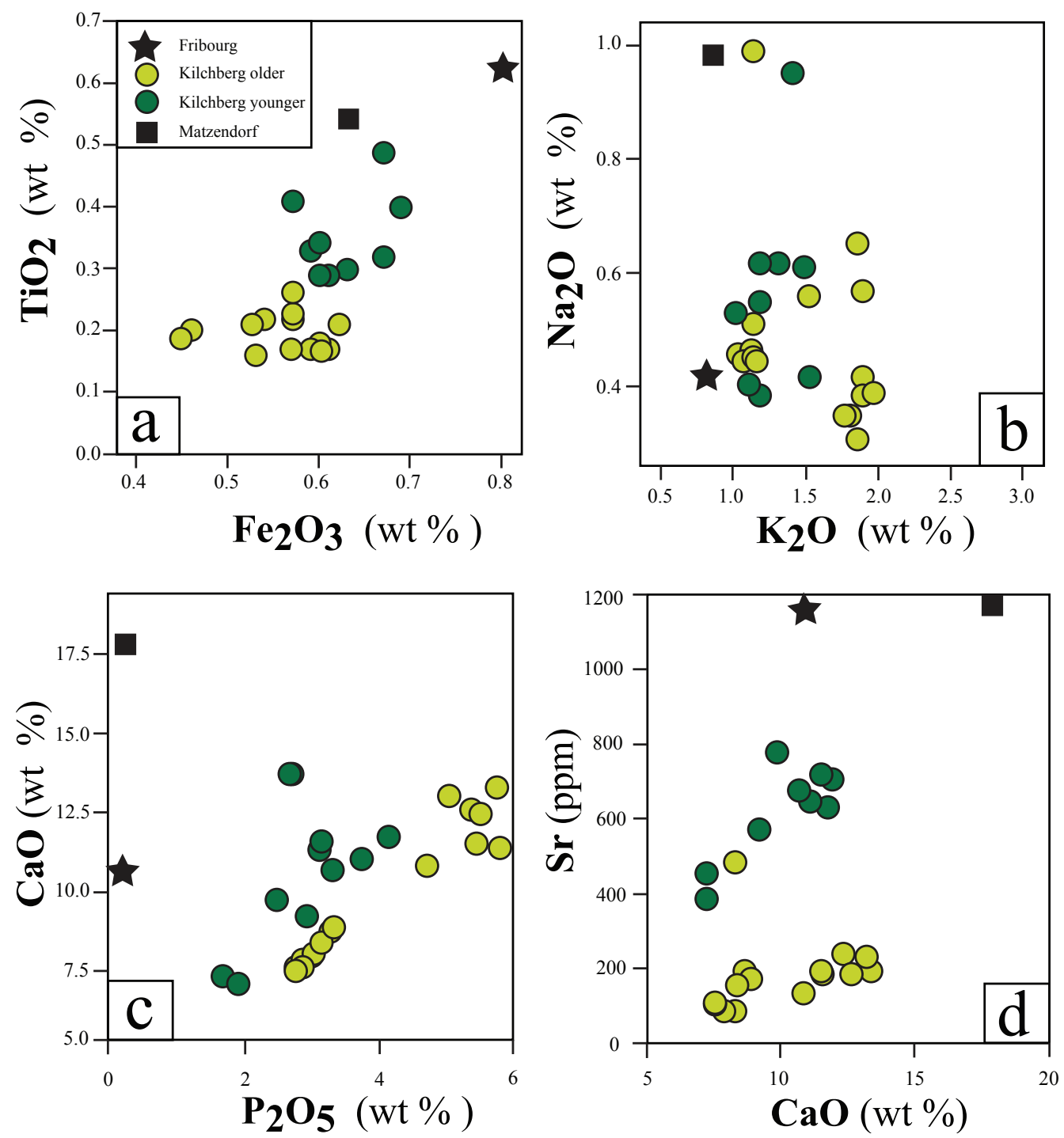

Figure 14. Body (bulk) compositions for the Eastern Swiss CaO-rich samples displayed on four selected binary diagrams. See discussion in the text. 
Table 6. Chemical compositions (XRF, Min.-Max.) of Swiss white earthenwares. Oxides in wt \%, elements in ppm.

\begin{tabular}{|c|c|c|c|c|c|c|c|c|c|c|}
\hline \multirow{3}{*}{ Date } & \multirow{3}{*}{$\begin{array}{c}\text { Fribourg } \\
1794-1810\end{array}$} & \multirow{3}{*}{$\begin{array}{c}\text { Matzendorf } \\
1800-1806\end{array}$} & \multicolumn{3}{|c|}{ Kilchberg-Schooren } & \multicolumn{5}{|c|}{ Nyon \& Carouge } \\
\hline & & & \multirow{2}{*}{ ca. $1800-1810$} & 1st Quarter of & \multirow{2}{*}{$\begin{array}{l}\text { 2nd Quarter of } \\
\text { 19th Century }\end{array}$} & \multicolumn{4}{|c|}{ Nyon: 1790-1930, Carouge: 1803-1879 } & \multirow{2}{*}{ Carouge 1880-1928 } \\
\hline & & & & 19th Century & & A & B & $\mathrm{C}$ & $\mathrm{D}$ & \\
\hline $\mathrm{N}$ analyses & 1 & 1 & 17 & 9 & 1 & 7 & 8 & 8 & 4 & 11 \\
\hline Reference & [62] & [19] & [64] & [64] & [58] & [37] & [37] & [37] & [37] & [37] \\
\hline $\mathrm{SiO}_{2}$ & 75.49 & 68.81 & $68.80-75.53$ & $63.80-75.53$ & 74.89 & $52.72-63.08$ & $52.45-60.54$ & $61.76-72.24$ & $66.63-72.33$ & 73.89-79.75 \\
\hline $\mathrm{TiO}_{2}$ & 0.62 & 0.54 & $0.16-0.26$ & $0.29-0.49$ & 1.42 & $0.50-0.84$ & $0.63-0.87$ & $10.49-0.78$ & $0.61-0.76$ & $0.32-0.65$ \\
\hline $\mathrm{Al}_{2} \mathrm{O}_{3}$ & 9.21 & 8.55 & $6.29-9.25$ & $10.91-16.21$ & 17.64 & $10.74-19.05$ & $11.93-16.89$ & $10.63-16.51$ & $11.12-15.93$ & $16.35-23.50$ \\
\hline $\mathrm{Fe}_{2} \mathrm{O}_{3}$ & 0.80 & 0.63 & $0.45-0.61$ & $0.57-0.69$ & 1.77 & $0.53-0.93$ & $0.59-0.76$ & $0.54-0.82$ & $0.55-0.69$ & $0.48-0.83$ \\
\hline $\mathrm{MnO}$ & 0.02 & 0.01 & 0.01 & 0.01 & 0.03 & & & & & \\
\hline $\mathrm{MgO}$ & 0.54 & 0.55 & $0.73-1.08$ & $0.39-0.65$ & 1.10 & $7.62-9.14$ & $2.98-6.77$ & $1.22-6.31$ & $0.30-0.41$ & $0.05-0.16$ \\
\hline $\mathrm{CaO}$ & 10.82 & 17.89 & $7.64-13.33$ & $7.32-11.74$ & 2.39 & $11.46-13.48$ & $15.66-19.75$ & $7.30-9.86$ & $7.14-8.85$ & $0.25-1.60$ \\
\hline $\mathrm{Na}_{2} \mathrm{O}$ & 0.42 & 0.98 & $0.35-0.99$ & $0.39-0.95$ & 0.26 & $0.39-1.31$ & $0.34-0.91$ & $0.74-1.27$ & $0.96-1.93$ & $0.28-1.08$ \\
\hline $\mathrm{K}_{2} \mathrm{O}$ & 0.81 & 0.86 & $1.05-1.98$ & $1.02-1.53$ & 0.70 & $1.68-2.24$ & $1.08-1.90$ & $1.48-2.33$ & $1.53-1.94$ & $0.64-1.89$ \\
\hline $\mathrm{P}_{2} \mathrm{O}_{5}$ & 0.23 & 0.21 & $2.80-5.77$ & $1.68-4.11$ & 0.06 & $0.04-0.05$ & $0.06-0.09$ & $0.04-0.05$ & $0.05-0.06$ & $0.06-0.17$ \\
\hline $\mathrm{Ba}$ & 232 & 185 & $14-557$ & $173-298$ & 297 & $246-346$ & $259-312$ & $186-279$ & $238-289$ & $139-696$ \\
\hline $\mathrm{Cr}$ & 41 & 41 & $8-37$ & $34-45$ & 158 & $74-110$ & 71-102 & $75-113$ & $69-87$ & $32-46$ \\
\hline $\mathrm{Cu}$ & 35 & 96 & $3-36$ & $4-55$ & 53 & $13-53$ & $29-67$ & $8-40$ & $12-54$ & $5-54$ \\
\hline $\mathrm{Nb}$ & 12 & 11 & $6-19$ & $9-15$ & 44 & $10-17$ & $14-17$ & $8-17$ & $10-15$ & $13-31$ \\
\hline $\mathrm{Ni}$ & 14 & 13 & $8-14$ & $11-15$ & 59 & $23-37$ & $19-35$ & $23-41$ & $25-31$ & $11-32$ \\
\hline $\mathrm{Pb}$ & 2151 & 2625 & $2100-10,365$ & $1361-21,827$ & 480 & $4666-24,511$ & $12,183-23,565$ & $4311-44,277$ & $18,441-34,528$ & $94-800$ \\
\hline $\mathrm{Rb}$ & 32 & 32 & $20-134$ & $47-86$ & 50 & $11-121$ & $8-46$ & $4-115$ & $27-52$ & $44-518$ \\
\hline $\mathrm{Sr}$ & 1164 & 1179 & $106-488$ & $387-778$ & 141 & 71-94 & $153-237$ & 78-196 & $165-251$ & $75-310$ \\
\hline Y & 19 & 23 & $11-66$ & $24-38$ & 16 & $8-61$ & $14-50$ & $6-55$ & $9-55$ & $11-33$ \\
\hline $\mathrm{Zn}$ & 45 & 222 & $21-62$ & $32-69$ & 42 & $32-61$ & $21-46$ & $31-62$ & $21-42$ & 28-190 \\
\hline $\mathrm{Zr}$ & 140 & 146 & 98-155 & $105-232$ & 182 & $104-250$ & $163-262$ & $51-217$ & $80-223$ & $121-188$ \\
\hline
\end{tabular}


The objects of the older period are $\mathrm{MgO}$-richer, but $\mathrm{TiO}_{2}$ - and $\mathrm{Sr}$-poorer (one exception) than the slightly younger pieces (Table 6, Figure $14 \mathrm{a}, \mathrm{d}$ ). This dichotomy is also nicely expressed in the $\mathrm{Sr}-\mathrm{CaO}$ diagram, which suggests that during both time spans two recipes were used with at least two $\mathrm{CaO}$ raw materials showing different $\mathrm{Sr} / \mathrm{Ca}$ ratios (Figure $14 \mathrm{~d}$ ).

The $\mathrm{P}_{2} \mathrm{O}_{5}$ content of the samples from this manufactory markedly exceeds the maximum of 0.7 wt \% found in the European white earthenware analyzed so far (Tables 2, 4 and 6; Figure 14c). Postfiring contamination (e.g., burial contamination through migrating P-rich solutions) and admixing of P-rich material (e.g., calcined bones) before firing are two processes normally advocated to explain such phosphorous anomalies (see literature in [66]). But such unusual P-concentrations could also be due to phosphoritic elements present ab initium in the clays [67]. In the present case, burial contamination can be ruled out because two foreign sherds from the same archaeological level have no such P-anomaly. The studied bodies contain many small grains with an internal microstructure typical for calcined bones (Figures 15 and 16a). The chemical composition of these grains, as determined by SEM-EDS, fits fairly well with a Ca-apatite, the inorganic mineral phase of bones.

This bone powder was added as an additional flux and represents a characteristic of the Kilchberg-Schooren production. One may wonder where the manufactory got this peculiar idea. Three bisques of the older production period carry the stamped mark of Johann Wilhelm Spengler, son of the first director of the porcelain manufactory Kilchberg-Schooren, who visited England (Derby) in 1790 and brought new forms and the secret of the white earthenware to Kilchberg [68]. Possibly he copied the idea of a phosphorous flux from the English bone china industry, though it is very astonishing that in the first years he produced a CaO-rich white earthenware in the French manner and not a CaO-poor creamware in the English tradition.

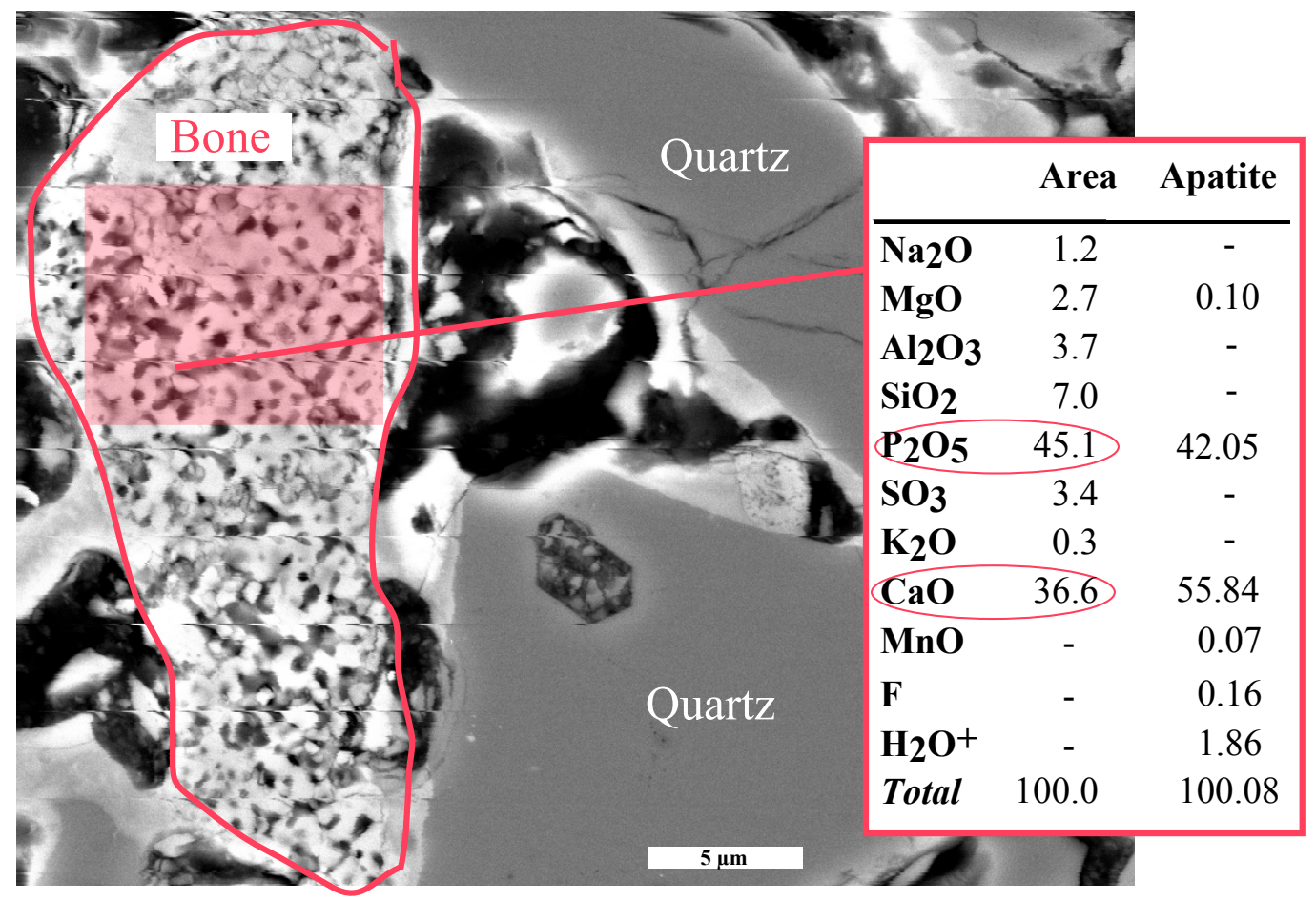

Figure 15. SEM-BSE image of a bone fragment with the typical microtexture and comparison of its composition (red area, wt \%) with that of an apatite. Kilchberg-Schooren, sample SH 22. Slightly modified from [64]. (C) Kantonsarchäologie Zürich.

In addition to bone, $\mathrm{Pb}$-bearing frit fragments were also added to the Kilchberg-Schooren paste mixture, as confirmed by SEM-BSE and EDS analyses [64] and the high Pb content of the bodies, which exceeds in some cases 1-2 wt \% (Table 6). 
The CaO-poor bisque of the 2nd quarter of the 19th century is chemically markedly different than the English and French CaO-poor samples of Table 2, as documented by its higher titania, magnesia and lime, and lower alumina.

The Fribourg and Matzendorf samples differ in some major and minor oxides and trace elements from the Kilchberg-Schooren products and can therefore be easily distinguished using simple binary diagrams (Figure 14). Their high Sr must be a specificity of the carbonate admixture, whose origin cannot yet be determined.

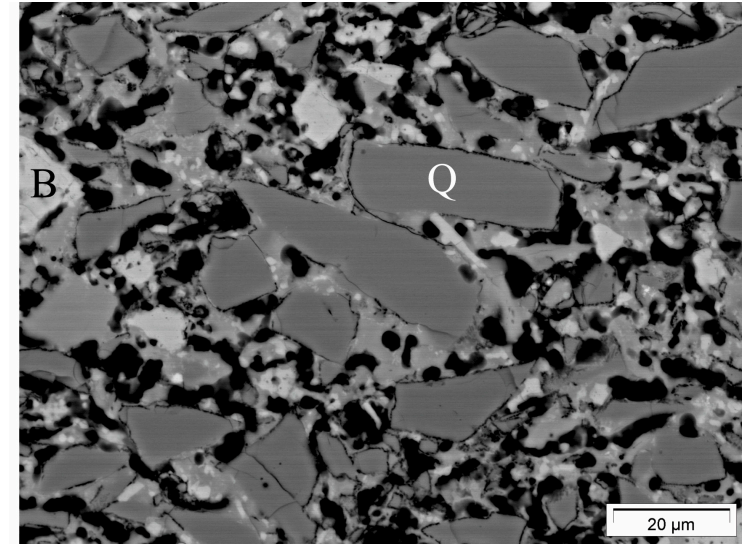

(a)

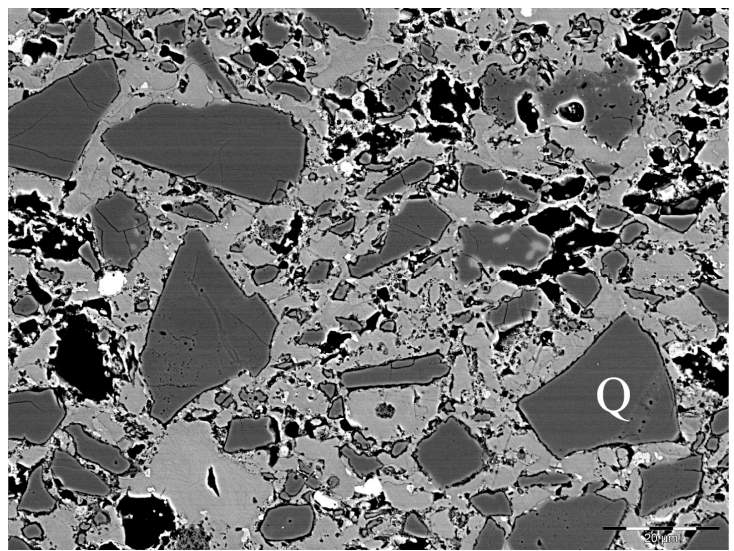

(b)

Figure 16. SEM-BSE image of Swiss CaO-rich white earthenware. (a) The body of the Kilchberg-Schooren sample $\mathrm{SH} 26$ shows angular quartzes $(\mathrm{Q}$, dark grey), some $\mathrm{CaO}-$ rich matrix patches (medium grey), bone fragments ( $\mathrm{B}$, whitish) and a high porosity (black voids); (b) The quartzes $(\mathrm{Q})$ in the Matzendorf sample BER 15 are somewhat smaller and are embedded in an abundant matrix. Very few bone fragments can be detected and the porosity is significantly lower compared to (a) [19]. Scale as in (a).

The SEM-BSE image of the Matzendorf specimen differs from that of Kilchberg-Schooren (Figure 16). Although comparable proportions of splintered quartz fragments can be seen in both, the quantity of matrix in the former is higher, which is reflected in a higher $\mathrm{CaO}$ content (Figure 14c). The angular outline of the quartz grains is a clear indication that quartz was added as a ground powder. Bone admixture is not mentioned in the Matzendorf manuscript recipe, but some bone chips could be detected. The SEM analysis showed no evidence of $\mathrm{Pb}$ frits, which fits well with the low $\mathrm{Pb}$ content of ca. $0.3 \mathrm{wt} \%$, most probably caused by contamination by the aqueous glaze suspension before firing and/or infiltration of $\mathrm{Pb}$ vapors or of the molten glaze during the firings (see discussion above). The microstructure of the Matzendorf sample is an artificial mixture of white firing clay, calcined quartz pebbles and chalk in a ratio of 2:1:1 as reported in [35]. According to the recipe and the BSE images of Matzendorf, the calcium could have been added as quicklime $\mathrm{CaO}$ or slaked lime $\mathrm{Ca}(\mathrm{OH})_{2}$ and not as the usual powdered chalk $\mathrm{CaCO}_{3}$. The clay was imported from Southern Germany over ca. $100 \mathrm{~km}$; i.e., from the village of Heimbach north of the town Freiburg i. Breisgau while the quartz pebbles were collected nearby, in the river Emme. Where the $\mathrm{CaO}$ raw material comes from is not known. The recipe book lists further mixtures, including some with only local raw materials. The variety of these recipes proves that Matzendorf constantly adapted their pastes. In addition to powdered bisque (grog) lead-free frits are also mentioned as compounding ingredients.

The analyses of white earthenwares from Western Switzerland led to the astonishing result that in Nyon, for more than a hundred years, from 1790 to 1930, only CaO- \& MgO-rich pastes were used (Table 6). This also applies to the products of the Carouge factories for the period 1803 to 1880. In both sites, the English and French technical progress has therefore been completely ignored. In 1880 however, a radical break with the past occurred in Carouge, where CaO-poor $(0.2-1.6 \mathrm{wt} \%)$, $\mathrm{SiO}_{2}-(70-79 \mathrm{wt} \%)$ and $\mathrm{Al}_{2} \mathrm{O}_{3}$-rich (16-23 wt \%) crockery was produced until 1936. 
The microstructure of the eleven $\mathrm{CaO}$-poor samples is similar (Figure 17). It shows a very fine-grained matrix composed of tiny quartz granules, former phyllosilicates and few $\mathrm{TiO}_{2}$ phases (rutile, anatase). The matrix contains four types of non-plastic inclusions: (1) angular $\mathrm{SiO}_{2}$ (quartz according to the XRD diffractograms) grains with maximum sizes of $100 \mu \mathrm{m}$. Their appearance is homogeneous without evidence of internal fracturing; (2) rare type A grains with angular contours and similar dimensions as the quartzes, showing in some cases partial melting at the borders. They are filled with small sticks or needles of a whitish color under the SEM, most likely mullite crystals embedded in a vitreous phase (Figure 17c); (3) fairly frequent grains, type B, with micromorphological aspects typical for kaolinite, with a maximum diameter of $30 \mu \mathrm{m}$, often showing signs of melting in contact with the matrix. Their outline goes from angular to rounded (Figure 17d); and (4) rare pores (maximum diameter $70 \mu \mathrm{m}$ ) with a compact and fine halo, typical of former calcite or limestone grains decomposed during firing.
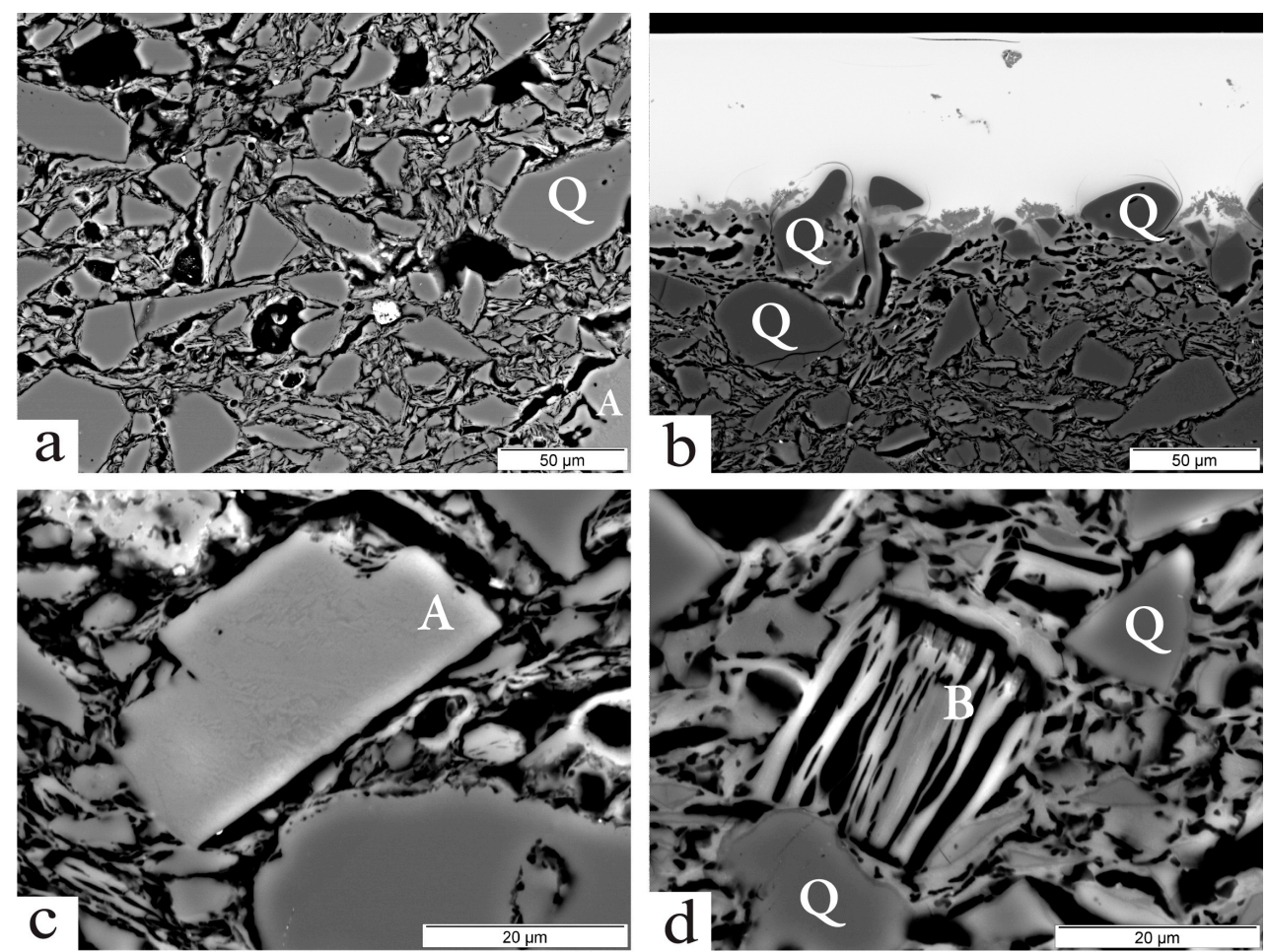

Figure 17. SEM-BSE images of CaO-poor white earthenwares [37]. (a) Ceramic body with many angular quartz fragments $(Q)$ in a fine grained matrix. Sample CAR 13. Picolas \& Neuenschwander, Carouge, 1880; (b) Contact glaze (above)-ceramic body (below) with obvious signs of quartz and matrix resorption by the liquid glaze during firing. CAR 16, Coppier \& $C^{\text {ie }}$, Carouge, 1904-1916; (c) Rectangular and sharp-edged type A grain, filled with microcrystals of lighter color, most likely mullite. CAR 11, Clément Coppier, Carouge, 1910-1928; (d) Type B grain with phyllosilicate appearance typical of a kaolinite cut parallel to the c-axis. CAR 15, Charles Degrange \& C ${ }^{\text {ie }}$, Carouge, 1885-1903.

The body is, according to the microstructural analysis, an artificial one, made by a mixture of white firing clays, quartzes (probably previously calcined) and other ingredients such as inclusion types A and B. The chemical composition of the matrix (without added non plastic inclusions) is very similar to that of the white firing clays of the Westerwald [16]. The angular contours of the quartz and the type A and B grains are clear evidence that these particles were added to the clays after thorough grinding.

The type A inclusions have a microscopic appearance and a chemical composition very close to that of similar type A inclusions of the Wedgwood tableware (see before). These were interpreted as 
$\mathrm{SiO}_{2}$-rich kaolinitic clays (ballclays) or mixtures of them with Cornwall Cornish stone, a kaolinitized peraluminous granite rich in feldspar [25]. For the Carouge tableware, the angular contour and their homogeneous nature indicate rather that they are grains obtained by the grinding of a feldspar rich granite of the Cornish stone type. The ceramic firing melted the feldspars and mullite crystallized out of the liquid on cooling.

Type B inclusions very often look like large grains of phyllosilicates cut parallel to their crystallographic axis c. The chemical composition brings them close to the type B inclusions of Wedgwood's crockery, although their microscopic aspect is different. The latter were interpreted as an aluminous ball clay admixture [25]. In the case of the studied Swiss sample, they are rather former crystals of kaolinite, as evidenced either by their characteristic (relic) appearance or their chemical composition, which is close to that of kaolinites. The potassium and iron content indicates that the original minerals, prior to their transformation into kaolinites, were micas.

In conclusion, the chemical and microstructural analyses of the youngest Carouge tableware suggest that their paste was probably a mixture of crushed quartz (sand), white firing clay, kaolin, and subordinate carbonate rock (Table 6, Figure 17). This fits well with the recipe of 1880 (in wt \%): 20 clay (a blend of four clay types) +41 kaolin (two types) +37 sand (two types) +2 chalk [36]. Due to the kaolin admixture they are no longer creamwares, but transitional types to the Queen's wares without kalifeldspar, see also Figure 7d.

The contact between the ceramic body and the glaze is sharp and often highlighted by an extremely thin layer of microcrystals. Precise chemical analysis of these crystals is very difficult because of their small size. They seem to be rich in $\mathrm{Si}, \mathrm{Al}, \mathrm{Pb}$, and $\mathrm{Ca}$. These crystals have their origin in the reactions between the glaze and the ceramic body that took place during the second (glaze) firing. Other important effects of these reactions are clearly visible, for example on quartz grains. In the ceramic body, their shape is angular, but round when immerged in the glaze at the contact body/glaze (Figure 17b). Evidently, these minerals were incorporated in the liquid glaze during firing. Where the grains were embedded, the matrix has also disappeared. It can be estimated that at least 10 microns of the body thickness were digested by these processes. Moreover, qualitative measurements showed a significant lead infiltration into the ceramic body, as still $0.4 \mathrm{wt} \% \mathrm{PbO}$ was detected in the body at a distance of $200 \mu \mathrm{m}$ from the contact with the glaze. Close to the contact and over a distance of ca. 40 microns, the microstructure of the body is very different from the rest, showing lower porosity and signs of partial melting. Both are induced by $\mathrm{Pb}$, which moved from the liquid glaze into the body during firing. According to [36], the temperature of the first (bisque) firing was at $1280^{\circ} \mathrm{C}$ while that of the second firing reached some $100{ }^{\circ} \mathrm{C}$ lower temperatures of about $1180^{\circ} \mathrm{C}$. This is corroborated by the presence of cristobalite and mullite in the diffractograms of the majority of the samples $(n=8)$, which indicate that they were fired above $1050^{\circ} \mathrm{C}$, by reference to the results of experimental firings of kaolinitic clays [51,52]. Two samples had to experience temperatures between 1050 and $950{ }^{\circ} \mathrm{C}$ and one a temperature close to $950^{\circ} \mathrm{C}$.

The chemical study of $28 \mathrm{CaO}-\& \mathrm{MgO}$-rich samples from western Switzerland (Carouge, Nyon) revealed an unexpected complexity, as four subgroups were found (Figure 18a). The first, group A, brings together all analyses with a $\mathrm{MgO} / \mathrm{CaO}$ ratio corresponding to an exclusively addition of a dolomite rock or the mineral dolomite (Figure 4 and related discussion). The richness in $\mathrm{CaO}$ and $\mathrm{MgO}$ of the bodies of the second, group $\mathrm{B}$, implies important additions of two carbonate ingredients: dolomite + limestone or a dolomitic limestone alone. The third, group $\mathrm{C}$, samples have variable $\mathrm{MgO} / \mathrm{CaO}$ ratios, reflecting additions of dolomite + limestone or dolomitic limestone alone, but at doses much lower than the second group. The objects of the fourth, group $\mathrm{D}$, show high $\mathrm{CaO}$ and very low $\mathrm{MgO}$ concentrations, fitting well with a limestone addition without dolomite.

This dual nature of the carbonatic ingredients finds its reflection in the distribution of the chemical elements as shown in the mappings. In the type B body of Figure 19, calcium appears to be related to small and distinct Mg-rich grains (=former dolomites), but few grains show much higher Ca-concentrations without any Mg-relation and are therefore former calcites. 


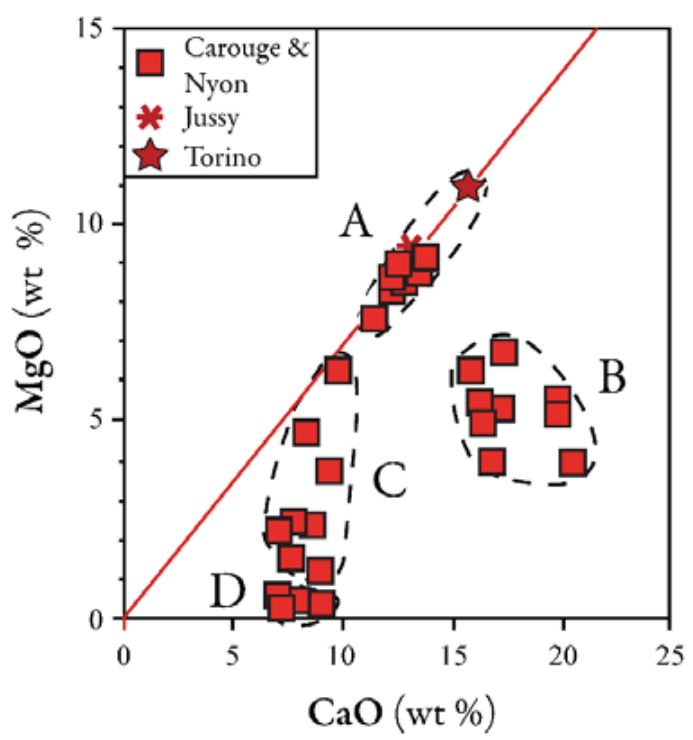

(a)

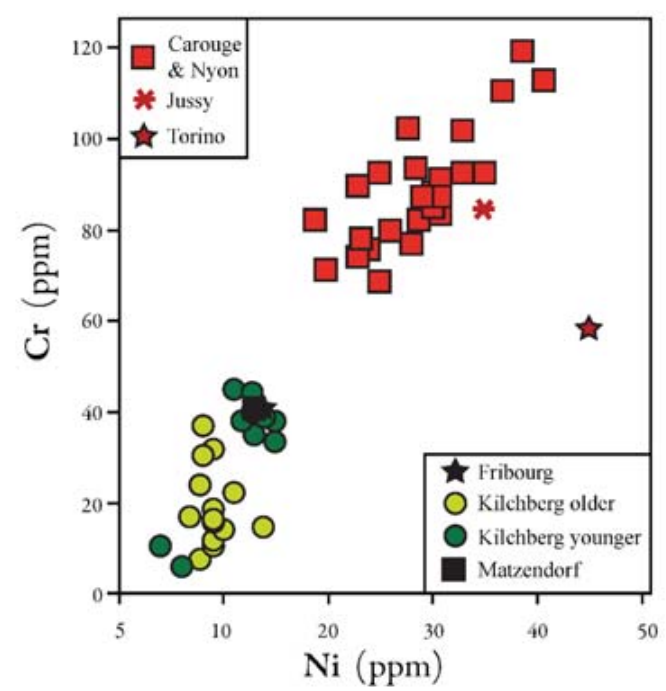

(b)

Figure 18. Body (bulk) compositions. (a) $\mathrm{MgO}-\mathrm{CaO}$ binary diagram: the Western Swiss (Carouge \& Nyon) CaO- \& MgO-rich samples, including one each from France (Jussy) and Italy (Torino), group in four distinct areas; (b) Differentiation of the Eastern (Fribourg, Kilchberg, Matzendorf) and Western Swiss CaO-rich samples with the C-Ni binary plot.
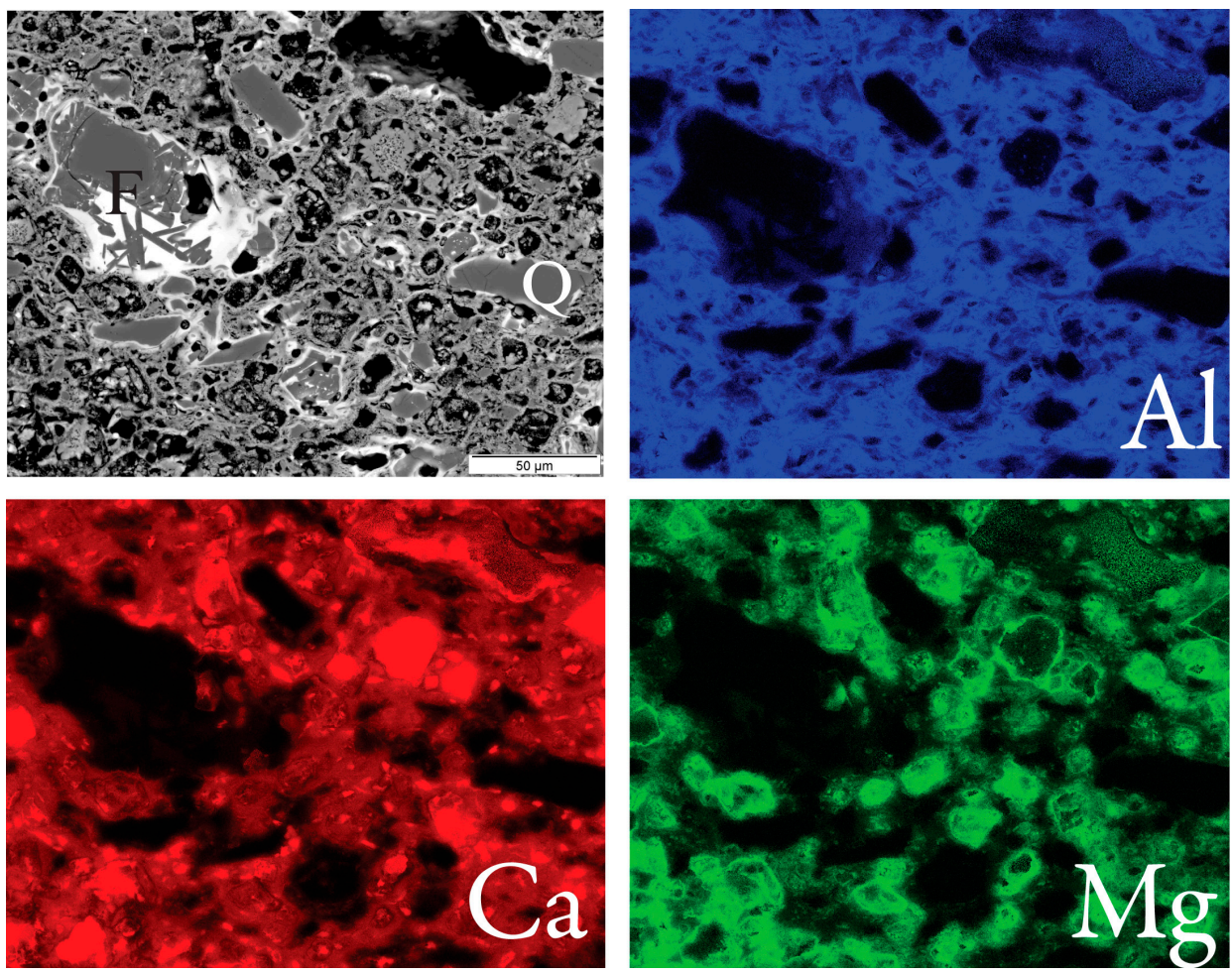

Figure 19. SEM-BSE image of a CaO-\&MgO-rich white earthenware from the Robillard \& $\mathrm{C}^{\text {ie }}$ manufactory in Nyon, 1818-1832/33 [25] (An. no. BER 9) showing angular fragments of crushed quartz (Q) and angular to subrounded fragments of coarser $\mathrm{PbO}-\mathrm{SiO}_{2}$-frits $(\mathrm{F})$, as well as the corresponding elemental maps of $\mathrm{Al}, \mathrm{Ca}$, and $\mathrm{Mg}$.

All western Swiss white earthenwares, except the youngest sample N10 of the years 1920-1930 (what probably shows the effects of the modern legislation in health matters), are rich in fragments of 
a lead frit, which are lacking in the bodies of the CaO-poor ware (Figures 19a and 20). It is therefore not surprising that the $\mathrm{Pb}$ concentrations reach almost $5 \mathrm{wt} \%$ (Table 6). Some of them contain small amounts of cassiterite crystals. The maximum diameter of these grains is less than $100 \mu \mathrm{m}$. They have a subangular outline, with a very sharp contact with the surrounding matrix. The $\mathrm{SnO}_{2}$-free frits consist of two phases, a lead-rich glass and $\mathrm{SiO}_{2}$ crystals. The latter are either irregularly shaped cores, or needles and rods surrounding these mostly roundish cores. These are interpreted to be relic quartzes having survived a complete fusion during the fritting process. The needles or rods crystallized from the $\mathrm{PbO}-\mathrm{SiO}_{2}$-rich liquid at the $\mathrm{T}$ climax and on the retrograde path during cooling of the frit. They could be tridymite or cristobalite. The amounts of vitreous phase versus $\mathrm{SiO}_{2}-\mathrm{phases}$ vary enormously, ranging from grains with a dominant glassy phase (Figure 20a) to grains consisting almost exclusively of $\mathrm{SiO}_{2}$ neoformations (Figure 20b), as those in the Lorraine samples.

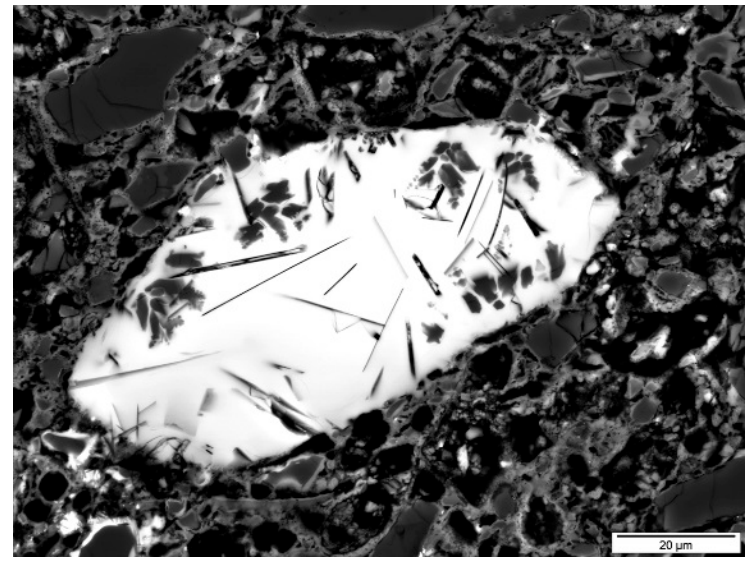

(a)

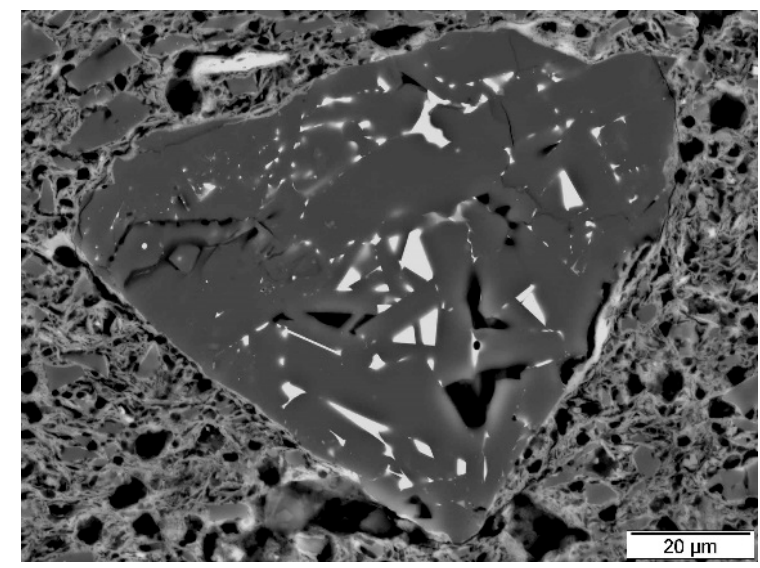

(b)

Figure 20. SEM-BSE images of two lead frits [37]. (a) Aspect of a grain very rich in lead glass (white) and few $\mathrm{SiO}_{2}$ phases (grey needles). Note the sharp contact with the matrix. BER 4, Dortu \& $\mathrm{C}^{\mathrm{ie}}$, Nyon, 1809-1813; (b) Aspect of a grain rich in $\mathrm{SiO}_{2}$ phases with some interstitial $\mathrm{PbO}-\mathrm{SiO}_{2}$ glass. The contact with the body matrix is sharp. CAR 12, Baylon, Carouge, 1822-1827.

The sharp boundary with the matrix shows that the glassy portions of the frits were not liquefied enough during the bisque and the glaze firings of the objects, and that mechanical infiltration of such a melt into the matrix could have occurred. Lead has diffused over a distance of ca. $10 \mu \mathrm{m}$ into the matrix, as evidenced by profile analyses. Such behavior corresponds well with the inferred maximum temperatures of $1050{ }^{\circ} \mathrm{C}$ for the firings (see below).

The microstructure of the bodies type A is very characteristic. It shows, apart from the mentioned ingredients (quartz, frit), many black pores with rectangular to rhombohedral contours and maximum diameters of $15 \mu \mathrm{m}$ (Figure 21a). Such voids also appear in body types B and C (Figure 21c). Some of these pores are filled with a cluster of tiny crystals. The SEM-EDS analyses indicate high $\mathrm{Mg}$ concentrations in these voids (Figure 19). The typical shape and the chemical composition indicate that these pores most likely correspond to former, ground dolomite grains that were dissociated during firing. The breakdown of the dolomite grains was not a simple process, as shown by a coarse grain with empty core, but still rich in magnesium, surrounded by a halo of calcium. Perhaps this element migrated towards the edge of the former dolomite rhombohedron or the observed feature is a primary one.

These four types of carbonate additions, either as minerals or rocks, were all reported in the recipes of Antoine Louis Baylon [32]. The chemical composition and the microscopic appearance of the objects analyzed reveal artificial paste mixtures similar to those described by this potter with the following ingredients: sand (from Cruseille) + white firing clay from Germany (Cologne) $+\mathrm{Pb}$ frit + chalk + Morez white + gypsum. The Morez white is most probably the source of the magnesium, but 
neither its exact nature (Pure dolomite? Rock or mineral?) nor its origin are known. According to Baylon, this ingredient replaces the chalk from France (Champagne) of earlier recipes, from which one can deduce that it must be a local carbonate. Importing chalk from France (Champagne) was an expensive operation and the financial aspect certainly played a crucial role. Replacing it by a local raw material was certainly a welcome pecuniary solution. There is however most likely an additional (technical) reason for this choice. The mineral dolomite dissociates at temperatures of $100{ }^{\circ} \mathrm{C}$ lower than those of calcite, as has been shown by many experimental firings of dolomitic clays (references in [37]). For a dolomitic paste, the appearance of firing minerals such as diopside, gehlenite, and plagioclase as well as the reorganization of the microstructure will therefore require a temperature of $100{ }^{\circ} \mathrm{C}$ less than in the case of a calcitic paste - a significant thermal, fuel, and financial advantage. It may be recalled that French and German faïence factories located on Triassic terrains used routinely dolomitic; i.e., magnesian marls $[69,70]$.
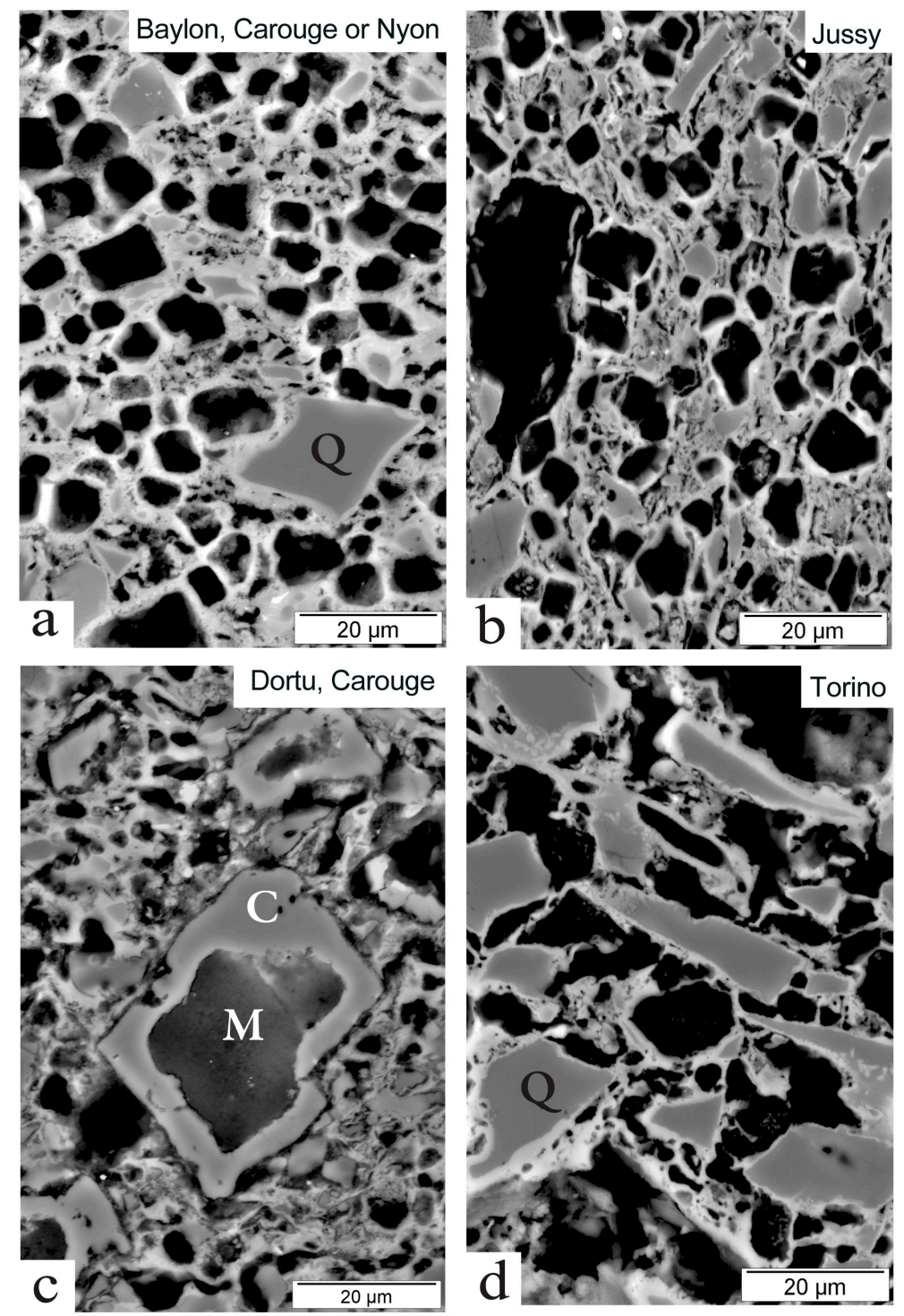

Figure 21. SEM-BSE images of four typical CaO- \& MgO-rich samples from Western Switzerland (Carouge, Nyon), France (Jussy) and Italy (Torino) [37]. (a) Body type A with angular fragments of quartz (grey, Q), square to rectangular pores (black) and a greyish matrix (Sample CAR 4); (b) Body type A (NYO 4); (c) This body type B contains large rhombohedral fragments with a MgO-rich core (M) and a CaO-rich border (C); (BER 13); (d) Body type A (CAR 8). 
$\mathrm{Pb}$ frits were added in many Central European pottery centers to CaO-rich pastes. This practice comes from the manufactories in Lorraine, who used them as an additional flux to the main carbonate flux (chalk from Champagne) to promote even better reactions during firing and to lower the firing temperatures. The French technical treatises of the first half of the 19th century extensively detail the recipes of contemporary Al-rich white earthenwares, but deliver very little useful information and no recipe for the $\mathrm{CaO}$-rich terre de pipe (see above). This is not very surprising because at that time, terre de pipe was no longer popular among the ceramic engineers, although it continued to be produced in many places, as exemplified for instance in Nyon. Fortunately, recipes have survived in handwritten sources that mention alkaline or lead-bearing frits [16] (Table 1). Both are detailed in Antoine Louis Baylon's workbook, but the chemical composition of the analyzed frits, all of the Si-Pb-Al-K-Ca type, does not match the recipes of A. L. Baylon. The cassiterite-bearing frit was also not mentioned by A. L. Baylon. This is very likely a waste product of the stanniferous glaze originated during the production of faïence, another ceramic type still produced in Carouge and Nyon alongside with the white earthenwares.

The 28 western $\mathrm{CaO}-\& \mathrm{MgO}$-rich samples are easily distinguishable from the eastern ones, for instance by the much higher chromium and nickel content. This is a trait they probably inherited from the ophiolithic chromites in the Cruseille sand (Figure 18b). On the other hand, there are hardly any important chemical and microstructural differences with Jussy's products. This is not surprising because the secret recipe of Nyon was sold in 1824 by Robillard to this manufactory [37].

The vast majority of the eastern and western Swiss products were fired at temperatures between 950 and $1050^{\circ} \mathrm{C}$, which most probably corresponds to those of the first (bisque) firing $[19,37,64]$.

\subsubsection{Glazes: Microstructures, Chemical Compositions and Technical Aspects}

The transparent, colorless and maximum $220 \mu \mathrm{m}$ thick $\mathrm{Al}_{2} \mathrm{O}_{3}$-rich $\mathrm{PbO}_{-} \mathrm{SiO}_{2}$ glaze of the studied Matzendorf sample is, except for a few needle-shaped crystals, inclusion-free (Figure 22a,b) [19]. The high concentration of $\mathrm{SiO}_{2}$ and $\mathrm{PbO}$ demonstrate the use of quartz and a lead compound. Salt can be recognized as a further ingredient on the basis of $\mathrm{Na}_{2} \mathrm{O}$ and chlorine values (Table 7). These ingredients correspond to those of the recipes as mentioned in the compendium called Arkanum [35]. There are three recipes for the period 1800-1806. The one dating from 1805 only lists four ingredients (in \%): 37 sand +40 minium +21 salt +2 alum. Potassia and alumina amounts seem to match the alum addition mentioned in the Arkanum. However, $1.5 \mathrm{wt} \% \mathrm{~K}_{2} \mathrm{O}$ from alum would give max. $1.6 \mathrm{wt} \% \mathrm{Al}_{2} \mathrm{O}_{3}$ from the alum. The high alumina must therefore be explained otherwise. Further, the magnesium and calcium contents cannot be explained with the pure raw materials mentioned in Matzendorf's recipe. It must therefore be assumed that the raw materials were not pure or that not all the ingredients are listed in the recipe. In addition, as already stated, chemical exchange process could have taken place between the glaze and the body, affecting the entire cross section of the glaze. The first case is probably the most likely, especially considering quartz sand, which may well have contained some percent kaolinite (Al supplier) and carbonate (Ca and Mg supplier). From these imponderables and the fact that in the glaze firing a large portion of sodium evaporates, the original composition of the glaze-raw material mixture cannot be reconstructed. A quantitative comparison with the Arkanum is therefore impossible. 
Table 7. Thicknesses and SEM-EDS analyses (wt \%) of Swiss and Italian white earthenware glazes.

\begin{tabular}{|c|c|c|c|c|c|c|c|c|c|}
\hline \multirow{2}{*}{ Date } & \multirow{2}{*}{$\begin{array}{c}\text { Matzendorf } \\
1800-1806\end{array}$} & \multicolumn{2}{|c|}{ Kilchberg-Schooren } & \multicolumn{4}{|c|}{ Nyon \& Carouge } & \multirow{2}{*}{$\begin{array}{c}\text { Carouge } \\
1880-1928\end{array}$} & \multirow{2}{*}{$\begin{array}{c}\text { Torino } \\
1824-1846\end{array}$} \\
\hline & & ca. $1800-1810$ & 1st quarter of 19 th century & & n: 1790-193 & ouge: $1803-$ & & & \\
\hline N samples & 1 & 3 & 1 & $\begin{array}{l}\text { A } \\
7\end{array}$ & $\begin{array}{l}\text { B } \\
8\end{array}$ & $\begin{array}{l}\mathrm{C} \\
8\end{array}$ & $\begin{array}{l}\mathrm{D} \\
4\end{array}$ & 11 & 1 \\
\hline Reference & [19] & [64] & [64] & [37] & [37] & [37] & [37] & [37] & [37] \\
\hline $\begin{array}{l}\text { Thickness } \\
(\mu \mathrm{m})\end{array}$ & 220 & & & $57-117$ & $35-99$ & $21-82$ & $42-84$ & 28-141 & 75 \\
\hline $\mathrm{Na}_{2} \mathrm{O}$ & 3.1 & $0.7-1.1$ & 1.2 & $0.3-1.8$ & $0.2-1.4$ & $0.2-2.7$ & $0.2-0.7$ & $0.5-1.7$ & 1.3 \\
\hline $\mathrm{MgO}$ & 1.3 & $0.4-0.6$ & 0.7 & $0.3-0.5$ & $0.3-1.4$ & $0.2-0.4$ & 0.2 & $0.1-0.8$ & \\
\hline $\mathrm{Al}_{2} \mathrm{O}_{3}$ & 6 & $4.4-5.7$ & 5.7 & $2.6-5.7$ & $3.1-4.7$ & $3.1-9.5$ & $3.3-5.0$ & $9.6-14.8$ & 5.1 \\
\hline $\mathrm{SiO}_{2}$ & 45.2 & $48.2-51.3$ & 48.3 & $28.2-55.9$ & $37.0-48.4$ & $38.4-66.6$ & $35.7-45.0$ & $49.9-60.4$ & 43.9 \\
\hline $\mathrm{Cl}^{2}$ & 0.2 & & & 0.4 & $0.4-0.5$ & $0.4-0.8$ & 0.5 & & \\
\hline $\mathrm{K}_{2} \mathrm{O}$ & 1.5 & $2.2-3.0$ & 2.9 & $0.9-3.8$ & $1.4-3.7$ & $0.7-5.2$ & $1.2-1.9$ & $2.2-3.2$ & 1.9 \\
\hline $\mathrm{SnO}_{2}$ & & $0.7-3.2$ & 0.3 & $(2.2)$ & & & & & \\
\hline $\mathrm{CaO}$ & 3.1 & $1.5-1.6$ & 3.2 & $0.2-2.2$ & $0.3-1.3$ & $0.1-0.5$ & $0.8-1.9$ & $3.1-7.7$ & 2 \\
\hline $\mathrm{TiO}_{2}$ & & & & 0.4 & 0.1 & $0.1-0.5$ & & 0.2 & \\
\hline $\mathrm{Fe}_{2} \mathrm{O}_{3}$ & 0.9 & $0.7-0.9$ & 0.6 & $0.4-0.6$ & $0.4-0.6$ & $0.4-0.6$ & $0.5-0.6$ & $0.3-2.1$ & 0.4 \\
\hline $\mathrm{PbO}$ & 38.8 & $33.1-40.0$ & 37.1 & $30.7-66.4$ & $40.0-56.0$ & $13.8-52.9$ & $45.1-56.9$ & $16.6-25.2$ & 45.4 \\
\hline
\end{tabular}


The glazes of the Kilchberg-Schooren $\mathrm{CaO}$-rich products are clearly $\mathrm{Na}_{2} \mathrm{O}$ - and $\mathrm{CaO}$-poorer, but $\mathrm{SiO}_{2}$ - and $\mathrm{K}_{2} \mathrm{O}$-richer than the Matzendorf glaze (Table 7). They are characterized by a significant tin oxide content that is absent in Matzendorf. Lorraine $\mathrm{CaO}$-rich white earthenwares have either a white opaque lead glaze with significantly higher $\mathrm{SnO}_{2}(8-10 \mathrm{wt} \%)$ or a colorless transparent $\mathrm{Pb}$ glaze (see above and Table 5). However, the $\mathrm{K}_{2} \mathrm{O}$ and $\mathrm{CaO}$ contents of the latter do not reach $1 \mathrm{wt} \%$ and are thus far below to that of the Eastern Swiss white earthenware.

The chemical analyses of glazes the Western (Carouge, Nyon) Swiss CaO- \& MgO-rich white earthenware are compatible with the ingredients of A. L. Baylon's recipes, either sand or pebbles + salt + minium or litharge + potash \pm alum [32] (Table 3), taking into account: (1) the decomposition of salt during the sintering of the mixture constituting the glaze, followed by the evaporation of sodium and chlorine during this process and then also during the firing of the glaze; and (2) the contamination of the glaze by reactions between it and the ceramic body (see below).
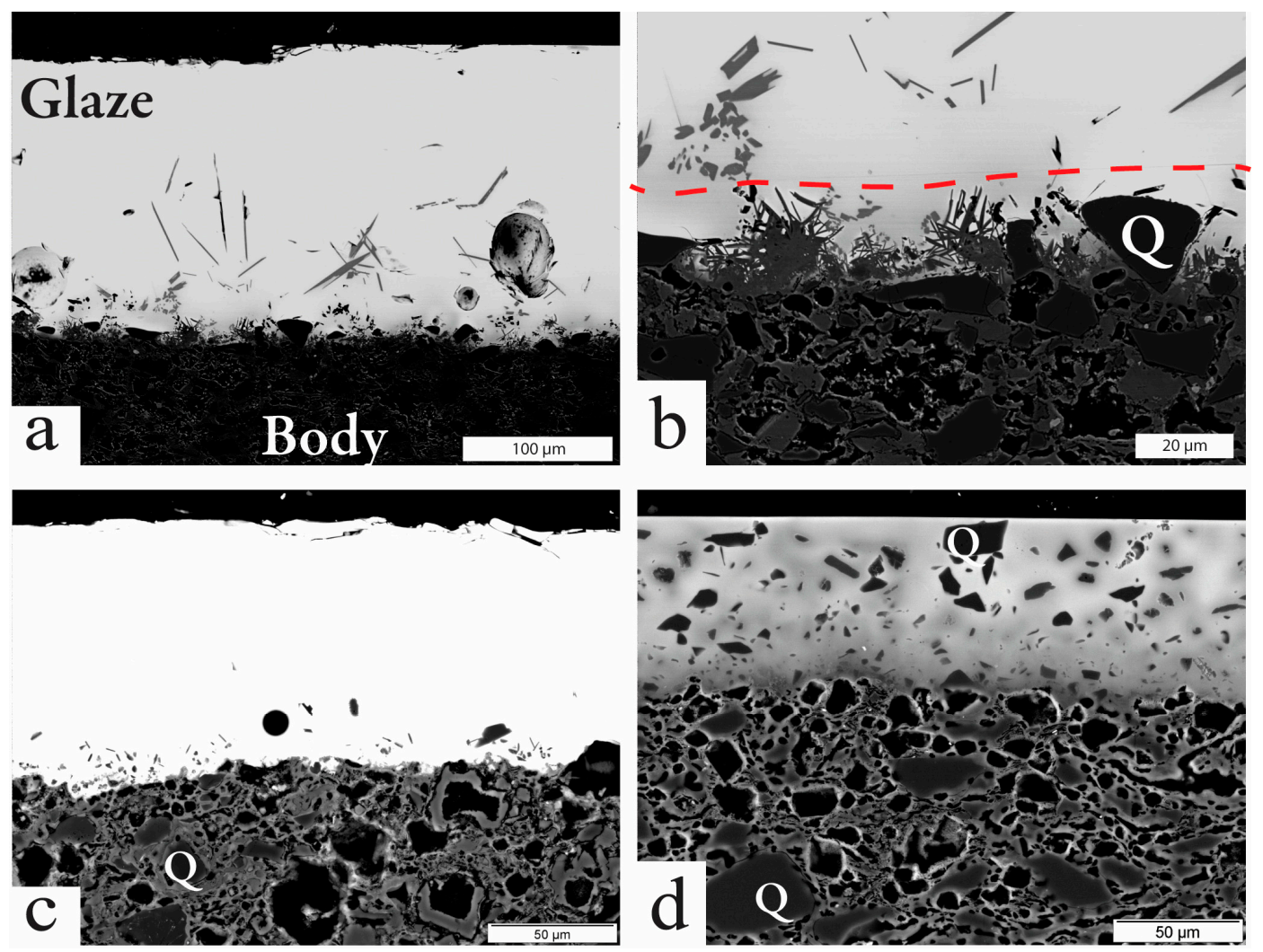

Figure 22. SEM-BSE images of Swiss lead glazes. (a) Macroscopically transparent glaze with many needle like crystals. Matzendorf, [19] (sample BER 15); (b) Close-up of (a) with the approximately 20 micron thick reaction zone (cluster of needle-like crystals and corroded body quartz in a glassy matrix) and the glaze with a few prismatic to acicular crystals. The dashed red line corresponds to the original (before firing) course of the contact between body and the glaze; (c) Macroscopically transparent glaze. Dortu, Carouge, 1813-1824, [37] (BER 13); (d) Macroscopically translucent glaze full of resorbed quartz grains. Poteries fines, Nyon, 1920-1923, [37] (NYO 10).

Under the microscope, the glazes have a very clear appearance, except NYO 10, which stands out for its richness in quartz grains (Figure 17c,d). For the latter, the potters added crushed quartz powder to the raw glaze. The glaze recipe of the youngest products (1920-1923) is therefore very different from the 19th century objects that did not use any secondary quartz powder. The angular shape of these quartzes suggests that they have not or only slightly reacted with the liquid glaze during the second firing of the ceramic object. Adding powdered quartz to the raw glaze was a common practice 
in 18th century French, German, and Swiss faïence manufactories [63,64,71-78]. The purpose of such a technique is unclear: increasing of the translucency of the glaze [79]? Compaction of the glaze powder [61]? No old or modern technical manual refers to this type of addition [72]. The fact that fusion of pure quartz gives a very viscous liquid could indicate a solution: the potters added crushed quartz simply to increase the viscosity of the molten glaze to prevent it from flowing too easily from the ceramic surface.

The contact glaze-ceramic body is sharp. But significant chemical reactions must have taken place between both, because granules of the body surrounded by the vitreous phase, visibly corroded quartz grains, and crystals of neoformation are observed in the glaze close to the contact. Such phenomena were also reported from the Matzendorf sample where the body lost at least 20 microns of its substance on a vertical section. For the Carouge and Nyon wares, it is probable that the glaze absorbed about 30 microns of the body on a vertical section, if the upper limit of the small crystals in the glaze is taken as representing the original surface of the body. Experimental firings have shown that $\mathrm{Al}$ of a pre-fired kaolinitic substrate migrates over a distance of 100-200 $\mu \mathrm{m}$ into a lead glaze [54]. Because the maximum thickness of the analyzed glazes was lower than $120 \mu \mathrm{m}$, a large part, if not all, of $\mathrm{Al}$ and probably also other chemical elements, could have been imported into the glaze by these high temperature reactions. Therefore, the chemical composition of the glazes no longer reflects the initial recipes. These complex digestion-diffusion reactions have been discussed in detail [53,54].

Even if the effects of the chemical reactions between the body and the glaze during firing are taken into account, it is to be noted that the glazes of the Al-rich white earthenwares from Carouge are much richer in $\mathrm{Al}_{2} \mathrm{O}_{3}, \mathrm{~K}_{2} \mathrm{O}$ and $\mathrm{CaO}$ than the $\mathrm{CaO}-\& \mathrm{MgO}$-rich white earthenwares from Carouge and Nyon, and also than the $\mathrm{Al}_{2} \mathrm{O}_{3}$-rich tableware of Pont-aux-Choux and Wedgwood (Table 3). Such a richness cannot be completely related to the chemical interactions body-glaze, but finds its explanation in the glaze recipe. This involves inter alia kaolin and a frit, which is composed of feldspar + kaolin + chalk + other ingredients. The high levels of $\mathrm{Al}_{2} \mathrm{O}_{3}$ are therefore due to kaolin and feldspar, those of $\mathrm{K}_{2} \mathrm{O}$ to feldspar and those of $\mathrm{CaO}$ to chalk. The lower values of these oxides in the $\mathrm{CaO}-\&$ $\mathrm{MgO}$-rich white earthenwares from Carouge and Nyon are easily explained by the absence of these three ingredients in their glazes recipes.

\subsection{Slovenian and Italian White Earthenware}

40 stamped and 46 non stamped white earthenware objects from the National Museum of Slovenia collections, originating from four Slovenian and three Italian manufactories (Figure 23), were recently studied with non-destructive analytical methods [45]. Table 8 reports only the results of the stamped ware. These are joined by an XRF and SEM-EDS analysis of one object from the Turin manufactory Dortu, Richard \& C ${ }^{\text {ie }}$ [37].

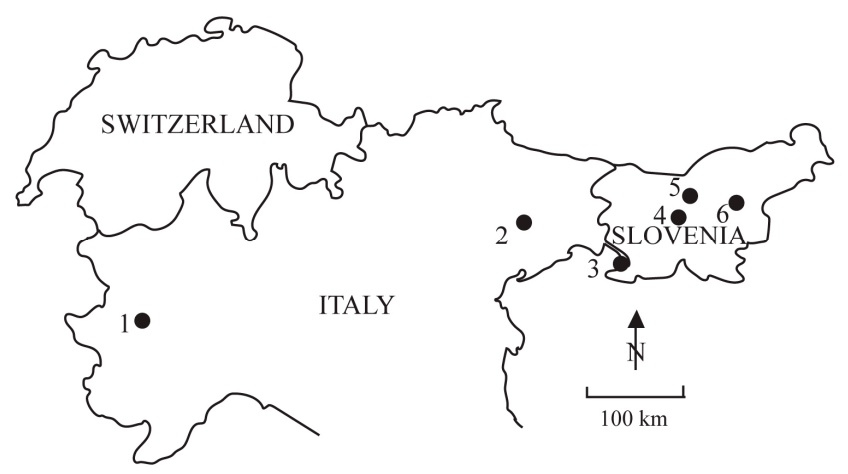

Figure 23. Map of Italy and Slovenia with the location of six white earthenware manufactories: 1 Torino (production start 1824), 2 Pordenone (1797), 3 Trieste (1776), 4 Ljubljana (1795), 5 Kamnik (1855), 6 Nemski dol (1817). 
Table 8. Chemical compositions (Min.-Max.) of Slovenian and Italian white earthenwares. Oxides and chlorine in wt \%, other elements in ppm.

\begin{tabular}{|c|c|c|c|c|c|c|c|c|c|}
\hline \multirow[b]{2}{*}{ Date } & \multicolumn{3}{|c|}{ Ljubliana } & \multirow{2}{*}{$\begin{array}{c}\text { Nemski dol } \\
1817-1928\end{array}$} & \multirow{2}{*}{$\begin{array}{c}\text { Kamnik } \\
\text { (Konjsek) } \\
1855-?\end{array}$} & \multicolumn{2}{|c|}{ Trieste } & \multirow{2}{*}{$\begin{array}{c}\text { Pordenone } \\
\text { (Galvani) } \\
1797-1855\end{array}$} & \multirow{2}{*}{$\begin{array}{c}\text { Torino } \\
1824-1846\end{array}$} \\
\hline & (Zois) & 95-1816 & $\begin{array}{c}\text { (Wasser) } \\
\text { 1817-1831 }\end{array}$ & & & $\begin{array}{c}\text { (Lorenzini) } \\
1776-1798\end{array}$ & $\begin{array}{c}\text { (Santini) } \\
1784-1813\end{array}$ & & \\
\hline $\mathrm{N}$ analyses & 12 & 2 & 7 & 1 & 6 & 4 & 5 & 3 & 1 \\
\hline Method & PIXE-PIGE & PIXE-PIGE & PIXE-PIGE & PIXE-PIGE & PIXE-PIGE & PIXE-PIGE & PIXE-PIGE & PIXE-PIGE & XRF \\
\hline Reference & $\begin{array}{c}{[45]} \\
\mathrm{CaO}-\text { rich }\end{array}$ & $\begin{array}{c}{[45]} \\
\mathrm{CaO}-\text { poor }\end{array}$ & [45] & [45] & [45] & [45] & [45] & [45] & [37] \\
\hline $\mathrm{SiO}_{2}$ & $36.8-68.0$ & $41.1-43.4$ & $52.0-62.5$ & 56.9 & $56.1-69.3$ & $54.8-71.7$ & $61.8-74.0$ & $53.1-62.0$ & 58.41 \\
\hline $\mathrm{TiO}_{2}$ & $0.11-0.23$ & $0.03-0.05$ & $0.12-0.44$ & 0.13 & $0.03-0.12$ & $0.13-0.17$ & $0.08-0.13$ & $0.12-0.15$ & 0.31 \\
\hline $\mathrm{Al}_{2} \mathrm{O}_{3}$ & $12.0-22.9$ & $4.72-10.0$ & $10.6-16.5$ & 15.5 & $9.71-20.4$ & $13.1-28.2$ & $5.84-15.9$ & $11.1-21.9$ & 11.70 \\
\hline $\mathrm{Fe}_{2} \mathrm{O}_{3}$ & $0.33-0.81$ & $0.21-0.23$ & $0.21-0.43$ & 0.19 & $0.16-0.37$ & $0.47-0.61$ & $0.50-0.86$ & $0.39-0.79$ & 0.59 \\
\hline $\mathrm{MnO}$ & $0.01-0.02$ & & $0.01-0.05$ & & $0.01-0.02$ & 0.01 & 0.01 & 0.01 & \\
\hline $\mathrm{MgO}$ & $0.75-4.93$ & $0.48-0.73$ & $1.44-4.01$ & 1.96 & $0.26-0.52$ & $0.81-2.17$ & $0.63-1.74$ & $1.24-1.36$ & 10.97 \\
\hline $\mathrm{CaO}$ & $6.58-32.6$ & $0.97-0.98$ & $13.1-21.9$ & 16.5 & $0.97-3.26$ & $5.88-7.30$ & $9.51-15.0$ & $9.53-12.5$ & 15.63 \\
\hline $\mathrm{Na}_{2} \mathrm{O}$ & $0.39-0.54$ & $0.18-0.20$ & $1.01-2.09$ & 1.62 & $2.47-3.95$ & $0.18-0.39$ & $0.43-0.90$ & $0.22-0.59$ & 0.63 \\
\hline $\mathrm{K}_{2} \mathrm{O}$ & $0.76-5.49$ & $1.16-1.47$ & $2.00-5.84$ & 4.69 & $1.39-2.47$ & $2.36-4.85$ & $1.45-2.41$ & $1.94-3.98$ & 0.63 \\
\hline $\mathrm{P}_{2} \mathrm{O}_{5}$ & & & & & & & & & 0.10 \\
\hline $\mathrm{SO}_{3}$ & $0.47-9.61$ & & $0.63-3.62$ & 0.67 & $1.50-2.02$ & $1.02-2.60$ & $1.00-5.94$ & $4.69-7.27$ & \\
\hline $\mathrm{Cl}$ & $0.06-0.62$ & $0.91-0.97$ & $0.06-0.31$ & 0.30 & $0.14-0.90$ & $0.13-0.23$ & $0.17-0.32$ & $0.19-0.36$ & \\
\hline $\mathrm{Ba}$ & & & & & & & & & 191 \\
\hline $\mathrm{Cr}$ & & & & & & & & & 58 \\
\hline $\mathrm{Cu}$ & 1050 & & & & & $400-580$ & & & 22 \\
\hline $\mathrm{Nb}$ & & & & & & & & & 7 \\
\hline $\mathrm{Ni}$ & & & & & & & & & 45 \\
\hline $\mathrm{Pb}$ & $5477-225,577$ & $412,165-443,727$ & $8344-65,073$ & 14,667 & $31,933-235,788$ & $27,292-107,682$ & $5384-55,884$ & $3527-99,328$ & 9242 \\
\hline $\mathrm{Rb}$ & & & & & & & & & 22 \\
\hline $\mathrm{Sr}$ & & & & & & & & & 156 \\
\hline $\mathrm{Y}$ & & & & & & & & & 12 \\
\hline $\mathrm{Zn}$ & $56-440$ & & $100-500$ & & 67 & $100-230$ & $100-200$ & $100-200$ & 83 \\
\hline $\mathrm{Zr}$ & & & & & & & & & 79 \\
\hline
\end{tabular}




\subsubsection{Body: Microstructures, Chemical Compositions and Technical Aspects}

For the production of the Slovenian pastes, white-firing clays of local or Italian origin have been mixed with chalk [45]. However, the PIXE-PIGE results in Table 8 show high $\mathrm{SO}_{3}$ values (up to ca. $10 \mathrm{wt} \%$ ), which were not discussed by the authors. They could be explained with gypsum admixtures providing they are not analytical errors. The chlorine values were not further addressed either. They could result from a contamination of the analyzed surfaces and/or a $\mathrm{NaCl}$ admixture in the recipe. Most Slovenian bodies belong to the CaO-rich group, and only two were made after a CaO-poor recipe, not noted by the authors. The most surprising, however, are the exceptionally high $\mathrm{Pb}$ contents, which reach up to $44 \mathrm{wt} \%$. The authors found a $\mathrm{PbO}$ concentration of $0.12 \mathrm{wt} \%$ below the surface, which they attributed to lead diffusion. However, such a contamination process was not discussed in detail and the measured $\mathrm{Pb}$ values (transformed into PbO: max. $47.8 \mathrm{wt} \%$ ) in the bodies far exceed these $0.12 \mathrm{wt} \% \mathrm{PbO}$, a fact that was not explained. In addition, prior to the chemical grouping, if the lead is indeed due to contamination, the analyses should have been converted to lead-free. As this did not happen, all the classifications and attributions of [45] must be reconsidered. If these high $\mathrm{Pb}$ values are really those of the body and not of both body and glaze, they could be explained not only by contamination processes (see discussion above), but also by the addition of $\mathrm{Pb}$ frits, as was the case in the Lorraine factories. A SEM-EDS study would clarify this.

For the analyses of the Italian white earthenwares from Pordenone and Trieste the same restrictive remarks apply as for the Slovenian. All have $\mathrm{CaO}$-rich bodies. Their high $\mathrm{Pb}$ is probably indicative of the use of $\mathrm{a} \mathrm{Pb}$ frit in the recipe of the three manufactories. In the case of Trieste, the older ones (Lorenzini production period) appear to be distinguished from the younger products (Santini period) by lower $\mathrm{CaO}$ and higher $\mathrm{K}_{2} \mathrm{O}$ values. The high $\mathrm{SO}_{3}$ concentrations of the three objects from the Galvani factory in Pordenone differentiate them from those of Trieste. The body of the sample from the Torino factory corresponds to a dolomitic ingredient, as shown in Figure 18a. It occupies the highest position on the red line, which indicates the highest dose by far of dolomite (rock or mineral) of all the white earthenware analyzed. It differs from the Swiss objects by a higher content of quartz inclusion and a higher porosity (Figure 21d). Regarding the $\mathrm{Cr}$ - and Ni-concentrations, Torino's sample is not part of the Swiss groups (Figure 18b). This is hardly surprising, since Frédéric Dortu, son of the director of the manufactory Carouge and founder of Torino, used only local resources for his recipe in Torino, dated 18 August 1829 (no unit given): 450 Mondovi earth +300 Calcium carbonate +400 frit [37]. The frit was made with 150 sand from Castelamont +18 litharge +6 potassia. The recipe of the paste and the frit can be found, but no information is given on the unit of measurement or where these local ingredients came from. At present, nothing is known about the Mondovi earth. It could be a white firing $\mathrm{Al}$ rich clay like the one from Cologne. Dortu also gives no information about the use of a quartz ingredient (sand) in his recipe. The fact that such an addition took place is confirmed by the BSE image (Figure 21d). And the calcium carbonate is perhaps a pure limestone as suggested by the recipe. However, according to the chemical analysis, it would rather be a dolomitic rock. It can be noted that for at least this piece the recipe of 1829 does not agree with the analyses. As only one object from Torino was examined so far, no firm conclusions on the entire production can be made.

The XRD phase association of the Torino sample is compatible with maximum firing temperatures in the interval $900-1050{ }^{\circ} \mathrm{C}$ [37].

\subsubsection{Glazes: Microstructures, Chemical Compositions and Technical Aspects}

Frédéric Dortu revealed in his recipe of 1829 no information on the glaze production. Clues to the glaze recipe must therefore rely on microscopical and chemical analyses. The glaze of the object from the Torino manufactory does not differ chemically and microstructurally from those of Carouge or Nyon. Accordingly, the statements made in this context also apply to the analyzed specimen. 


\section{Conclusions}

1. White earthenware was produced in Europe in enormous quantities in small factories as well as in large industries from the middle of the 18th century onwards. However, archaeometric studies are just at the beginning.

2. Traditional potters, for example those of the tin-glazed faïence manufactories, used successful recipes for the bodies and the glaze for decades into the 19th century. In contrast, the recipe books of the white earthenware potters and the archaeometric analyses prove that these potters constantly changed and adapted the recipes. The detection and pursuit of this technical evolution is an exciting archaeometric research field.

3. The white earthenware pastes or their fired counterpart, the bodies, are artificial mixtures. Two technical traditions can be recognized in Europe. In England, only CaO-poor clays were used. These were mixed with ground flint (creamware) and later additionally with kaolinite and Cornish stone (Queen's ware). In France, CaO-poor as well as $\mathrm{CaO}$-rich pastes were used. The first type, a blend of a CaO-poor clay with grog, is the one applied in Paris (e.g., Pont-aux-Choux manufactory). CaO-poor clays were also used in Lorraine, but mixed with marls or limestones, fritted quartz pebbles and lead frits (terre de pipe). Over time, these recipes were replaced by the more successful English one. First by a paste made of $\mathrm{CaO}$-poor clays mixed with quartz powder leading to the so-called cailloutage, and later with additionally kaolinite and other raw materials rich in potassium feldspars. This resulted in a product called faïence opaque, porcelaine opaque etc.

4. In addition to $\mathrm{CaO}$-rich ingredients (calcite, limestone, marl), glassy frits and kalifeldspar-rich raw materials, other fluxes such as bone ash or dolomite were also experimented. Further flux types are lime, chalk, giobertite (magnesite $\mathrm{MgCO}_{3}$ ), pegmatite, glass, and fusible sand [23].

5. Starting from France, the $\mathrm{CaO}-$ rich technique spread throughout Central Europe. Some manufactories retained this recipe until the beginning of the 20th century, obviously for financial reasons, while others switched in the first half of the 19th century to the more shock resistant CaO-poor pastes.

6. In Western Switzerland (Carouge, Nyon) and in the neighboring French (Jussy, Meillonnas) and Italian (Torino) manufactories, dolomitic raw materials were used, probably because of the lower firing temperatures (cost issue). The geographic and temporal extension of this regional feature has yet to be clarified.

7. White earthenware is fired twice, first in the bisque, then in the glaze firing. In CaO-rich products, the bisque firing temperature is lower than the glaze firing temperature, but higher in $\mathrm{CaO}$-poor specimens. During the second firing, important physico-chemical reactions between the aggressive liquid lead glaze and the underlying body profoundly change the initial chemical composition of the raw glaze. Therefore, in many cases, the original glaze recipe cannot be calculated from the oxide concentrations.

Acknowledgments: The author is grateful to Marco Benvenuti for the invitation to write this paper. He thanks Andreas Heege for the discussion concerning the nomenclature and the reference to the Dutch terminology (e.g., white bodied industrial earthenware), an anonymous reviewer for his helpful comments and Jane Favre for the careful revision of the English.

Conflicts of Interest: The author declares no conflict of interest.

\section{References}

1. Crépin-Leblond, T. Une céramique de cour. In Une Orfévrerie de Terre. Bernard Palissy et la Céramique de Saint-Porchaire; Crépin-Leblond, T., Ennès, P., Eds.; Réunion des Musées Nationaux: Paris, France, 1997; pp. 19-27, ISBN 2711835650, 9782711835652. (In French)

2. Munier, P. Contribution à l'étude des céramiques de Bernard Palissy. Bull. Soc. Fr. Céram. 1949, 3, $27-48$. (In French) 
3. Dufaÿ, B.; de Kisch, Y.; Poulain, D.; Roumégoux, Y.; Trombetta, P. L'atelier parisien de Bernard Palissy. Rev. Art 1987, 78, 33-60. (In French) [CrossRef]

4. Maire, C. Histoire de la Faïence Fine Française 1743-1843. In Le Triomphe des Terres Blanches; Reinette: Paris, France, 2008; ISBN 978-2-913566-54-5. (In French)

5. Dawson, A. The Growth of the Staffordshire Ceramic Industry. In Pottery in the Making. World Ceramic Traditions; Freestone, I., Gaimster, D., Eds.; British Museum Press: London, UK, 1997; pp. 200-205, ISBN-10: 071411782X.

6. Heimann, R.B.; Maggetti, M. Ancient and Historical Ceramics. Materials, Technology, Art, and Culinary Traditions; Schweizerbart Science Publishers: Stuttgart, Germany, 2014; pp. 255-278, ISBN 978-3-510-65290-7.

7. Towner, D. Creamware; Faber \& Faber: London, UK, 1978; p. 540, ISBN 978-0571049646.

8. Massey, R. Understanding Creamware. In Creamware and Pearlware Re-Examined; Walford, T., Massey, R., Eds.; English Ceramic Circle: London, UK, 2007; pp. 15-30, ISBN 978-0955532900.

9. Roberts, G.B. Early Wedgwood Creamware 1759-1769. In Creamware and Pearlware Re-Examined; Walford, T., Massey, R., Eds.; English Ceramic Circle: London, UK, 2007; pp. 51-64, ISBN 978-0955532900.

10. Hosotte-Reynaud, M.A. La manufacture de Pont-aux-Choux 1743-1788. Mémoires de la Fédération des Sociétés Historiques et Archéologiques de Paris Ile de France 1967, 16-17, 271-297. (In French)

11. Le Duc, G. Paris, Rue de Charenton. Une Manufacture Royale de "Terre d'Angleterre" 1743-1749; Revue de la Société des Amis du Musée National de Céramique: Sèvres, France, 1993; Volume 2, pp. 20-28, ISSN-L 1169-2537. (In French)

12. De la Hubaudière, C.; Soudée Lacombe, C. Edme Serrurier "Entrepreneur de la Manufacture Royalle des Terres d'Angleterre Etablie à Paris"; Revue de la Société des Amis du Musée National de Céramique: Sèvres, France, 2003; Volume 12, pp. 9-18, ISSN-L 1169-2537. (In French)

13. De Plinval de Guillebon, R. Faïence et Porcelaine de Paris, XVIII -XIX ${ }^{e}$ siècles; Editions Lilou: Quimper, France, 1995; ISBN 978-2878440225. (In French)

14. Dawson, A. 18th century French Creamware. In Creamware and Pearlware Re-Examined; Walford, T., Massey, R., Eds.; English Ceramic Circle: London, UK, 2007; pp. 205-217, ISBN 978-0955532900.

15. Peiffer, J.G. Faïences à corps blanc. In Série Blanche: La Céramique, Naissance d'une Industrie au Coeur de L'europe; Chariot, C., Decker, E., Eds.; Musée gaumais et Musée de Sareguemines: Sarreguemines, France, 2007; pp. 81-165, ISBN 978-291379015. (In French)

16. Maggetti, M.; Rosen, J.; Serneels, V. White earthenware from Lorraine (1755-c.1820): Provenance and technique. Archaeometry 2011, 53, 765-790. [CrossRef]

17. Stoehr, A. Deutsche Fayencen und Deutsches Steingut. Ein Handbuch für Sammler und Liebhaber; Schmidt, R.C. \& Co.: Berlin, Germany, 1920. (In German)

18. Morazzoni, G. La Terraglia Italiana; Alfieri, L.: Milano, Italia, 1956; ASIN B0028U35AC. (In Italian)

19. Maggetti, M. Technologische Analyse eines frühen (1800-1806) Matzendorfer Steinguts. Mitt. Keram.-Freunde Schweiz 2017, 131, 105-123. (In German)

20. Oppenheim, M. L'art de Fabriquer la Poterie, Façon Anglaise: Contenant les Procédés et Nouvelles Découvertes, la fabricatIon du Minium, Celle d'une Nouvelle Substance Pour la Couverte, celle des Couleurs Vitrifiables, l'Art d'Imprimer sur Fä̈ence et Porcelaine, et un Vocabulaire des Termes Techniques et Chimiques. Revu Pour la Partie Chimique par M. Bouillon-Lagrange; Librairie Debray, A.G.: Paris, France, 1807. (In French)

21. Brongniart, A. Traité des Arts Céramiques ou des Poteries Considérées dans leur Histoire, leur Pratique et leur Théorie; Béchet Jeune: Paris, France, 1844; 3 volumes and 1 atlas. (In French)

22. Bastenaire-Daudenart, F. L'Art de Fabriquer la Fä̈ence Blanche Recouverte d'un Émail Transparent à l'Instar Français et Anglais, Suivi d'un Traité de la Peinture au Réverbère, et d'un Vocabulaire des Termes Techniques; de Malher \& Cie.: Paris, France, 1830. (In French)

23. Boyer, M. Manuel du Porcelainier, du Fä̈encier, du Potier de Terre; Manuel Roret: Paris, France, 1827. (In French)

24. Peiffer, J.G. Une confusion historique: Terre de pipe et faïence fine. In Fä̈ence Fine et Porcelaine. Les Hommes, Les Objets, Les Lieux, Les Techniques; Minovez, J.J., Ed.; CNRS Université de Toulouse-le-Mitrail: Toulouse, France, 2003; pp. 23-46, ISBN 978-2-912025-13-5. (In French)

25. Maggetti, M.; Heege, A.; Serneels, V. Technological aspects of an early 19th c. English and French white earthenware assemblage from Bern (Switzerland). Period. Mineral. 2015, 84, 139-168. [CrossRef]

26. Salmang, H.; Scholze, H. Die Physikalischen und Chemischen Grundlagen der Keramik, 5th ed.; Springer: Berlin, Germany, 1968. (In German) 
27. Tite, M.S. Iznik pottery: An investigation of the methods of production. Archaeometry 1980, 31, 115-132. [CrossRef]

28. Schneider, G. A technological study of north-Mesopotamian stone ware. World Archaeol. 1989, 21, $29-50$. [CrossRef]

29. Tite, M.S.; Wolf, W.; Mason, R.B. The technological development of stonepaste ceramics from the Islamic Middle East. J. Archaeol. Sci. 2011, 38, 570-580. [CrossRef]

30. De la Hubaudière, C.; Soudée-Lacombe, C. "L'art de la Fayence" des Caussy, Fä̈enciers à Rouen et Quimper au XVIII Siècle; Lilou: Quimper, France, 2007; ISBN 978-2951023314. (In French)

31. Delvaux, P. Les Faïenciers d'Aprey; Foulard: Paris, France, 1908. (In French)

32. Maggetti, M. Analyse historique et technologique du carnet de notes du faïencier carougeois Antoine Louis Baylon. Mitt. Keram.-Freunde Schweiz 2017, 131, 124-157. (In French)

33. Ducret, S. Die Lenzburger Fayencen und Öfen des 18. und 19. Jahrhunderts; AZ Presse: Aarau, Switzerland, 1950. (In German)

34. Sigrist, R.; Grange, D. La Faïencerie des Pâquis. Histoire d'une Expérience Industrielle 1786-1796; Passé Présent: Geneva, Switzerland, 1995; ISBN 2-040014-09-4. (In French)

35. Felchlin, M. Das Arkanum der Matzendorfer Keramik. Jahrb. Soloth. Gesch. 1971, 44, 7-55. (In German)

36. Houriet, M.-O.; Houriet, J.-M. Les Fä̈enceries de Carouge; Skira: Geneva, Switzerland, 1985; ISBN 2-605-00063-X. (In French)

37. Maggetti, M.; Serneels, V. Etude archéométrique des Terres Blanches (Faïences fines) des manufactures de Carouge, Jussy, Nyon et Turin. Mitt. Keram.-Freunde Schweiz 2017, 131, 158-222. (In French)

38. Brosio, V. Dortu Tinelli Richard. Porcellane e maioliche dell'Ottocento a Torino e Milano; Görlich: Milano, Italy, 1972; ISBN 13: 2560007288026. (In Italian)

39. Frick, G. Die Kunst Weisses Steingut mit Durchsichtiger Glasur nach Art der Franzosen und Engländer Anzufertigen; Nebst Einer Abhandlung über die im Muffelfeuer Eingeschmolzenen Steingutfarben. Aus dem Französischen des Bastenaire-Daudenart übertragen; Voigt B. F.: Ilmenau, Germany, 1832. (In German)

40. Société d'Encouragement. Mémoire sur la fabrication des poteries, des faïences et des grès, à l'imitation des produits anglais, introduite en France par M. de Saint-Amans. Bull. Soc. d'Encourag. l'Ind. Nationale 1829, 28, 15-25, 83-92, 152-158. (In French)

41. Schumann, L.F. Die Kunst, Durchsichtiges Porzellan und Weisses Steingut mit Durchsichtiger Glasur Anzufertigen. Nebst Einer Gründlichen Anleitung zur Erbauung der Einfachsten und Vortheilhaftesten Massenmühlen, Schlemmerei, Massenkochöfen, Brennöfen und Abdrehmaschinen, so wie Einer Ausführlichen Abhandlung über die Laboration der Mineralfarben für Porzellan-, Steingut-, und Glasurmalerei, mit der Nöthigen Anweisung zur Erbauung der zum Einschmelzen Angewandter Holz- und Kohlenmuffen; Voigt B.F.: Weimar, Germany, 1835. (In German)

42. Salvétat, M.A. Leçons de Céramique Professées à l'Ecole Centrale des Arts et Manufactures, ou Technologie Céramique, Comprenant les Notions de Chimie, de Technologie et de la Pyrotechnie, Applicables à la Fabrication, à la Synthèse, à L'analyse, à la Décoration des Poteries; Mallet-Bachelier: Paris, France, 1857. (In French)

43. Munier, P. Technologie des Fä̈ences; Gauthier, Villars: Paris, France, 1957. (In French)

44. Tite, M.S. Comparative Study of the Production Technology for "Saint-Porchaire" and Related European Ceramics. In Saint-Porchaire Ceramics; Barbour, D., Sturman, S., Eds.; Studies in the History of Art Monography Series 52; Monograph Series II; National Gallery: Washington, DC, USA, 1996; pp. 99-105, ISBN 978-0894682131.

45. Kos, M.; Smit, Z. PIXE-PIGE analysis of 18 th and early 19th century creamware from Slovenia and Northern Italy. J. Cult. Herit. 2011, 12, 236-242. [CrossRef]

46. Ionescu, C.; Ghergari, L. Modelling and firing technology- reflected in textural features and the mineralogy of the ceramics from Neolithic sites in Transsylvania (Romania). Geol. Carpath. 2002, 53, 6.

47. Whitbread, I.K. The characterization of argillaceous inclusions in ceramic thin sections. Archaeometry 1986, 28, 79-88. [CrossRef]

48. Cuomo di Caprio, N.; Vaughan, S.J. An Experimental Study in Distinguishing Grog (Chamotte) from Argillaceous Inclusions in Ceramic Thin Sections. Archaeomaterials 1993, 7, 21-40.

49. Turekian, K.K.; Wedepohl, K.H. Distribution of the elements in some major units of the Earth's crust. Geol. Soc. Am. Bull. 1961, 72, 175-192. [CrossRef] 
50. Lovering, T.G. Abundance of lead in sedimentary rocks, sediments, and fossil fuels. In Lead in the Environment; Lovering, T.G., Ed.; Geological Survey Professional Paper 957; US Geological Survey: Washington, DC, USA, 1976; pp. 31-34.

51. Maggetti, M.; Rossmanith, M. Archaeothermometry of Kaolinitic Clays. Rev. d'Archéom. 1981, 1, $185-194$. [CrossRef]

52. Maggetti, M. Phase Analysis and its Significance for Technology and Origin. In Archaeological Ceramics; Olin, S.J., Franklin, A., Eds.; Smithsonian Institution Press: Washington, DC, USA, 1982; pp. 121-133.

53. Vendrell-Saz, M.; Molera, J.; Roqué, J.; Pérez-Arantegui, J. Islamic and Hispano-Moresque (mudejar) lead glazes in Spain: A technological approach. In Geomaterials in Cultural Heritage; Maggetti, M., Messiga, B., Eds.; The Geological Society of Landon, Special Publication 257: London, UK, 2006; pp. 163-173, ISBN 1-86239-195-5.

54. Molera, J.; Pradell, T.; Salvado, N.; Vendrell-Saz, M. Interactions between clay bodies and lead glazes. J. Am. Ceram. Soc. 2001, 84, 120-128. [CrossRef]

55. Rosen, J.; Maggetti, M. En Passant par la Lorraine... Un Nouvel Éclairage sur les Faïences et les "Terres Blanches" du Bois d'Épense/Les Islettes, de Lunéville et de Saint-Clément; Mitteilungsblatt der Keramikfreunde der Schweiz: Oberglatt, Switzerland, 2012; Volume 126, ISBN 978-3-033-03695-6. (In French)

56. Rosen, J. La Manufacture de Meillonnas (Ain). Etude d'une Fabrique de Céramique Régionale 1760-1870; Monique Mergoil: Montagnac, France, 2000; ISBN 2-907303-30-9. (In French)

57. Macquer, P.J. Dictionnaire de Chimie, Contenant la Théorie et la Pratique de Cette Science; Barrois: Paris, France, 1778. (In French)

58. Maggetti, M.; Galetti, G. Naturwissenschaftliche Analyse der Fayence von Matzendorf. In 200 Jahre Keramische Industrie in Matzendorf und Aedermannsdorf 1798-1998; Verein Freunde der Matzendorfer Keramik, Ed.; Verein Freunde der Matzendorfer Keramik: Matzendorf, Switzerland, 2000; pp. 99-183. (In German)

59. Maggetti, M. Technology and Provenancing of French faience. In Archaeometry and Cultural Heritage: The Contribution of Mineralogy, Seminar in Bilbao, Spain, 27 June 2012; Herrero, J.M., Vendrell, M., Eds.; Seminarios de la Sociedad Espanola de Mineralogia 09; Sociedad Esapnola de Mineralogia: Madrid, Spain, 2012; pp. 41-64, ISSN 1698-5478.

60. Tite, M.S.; Freestone, I.; Mason, R.; Molera, J.; Vendrell-Saz, M.; Wood, N. Lead glazes in Antiquity-Methods of production and reasons for use. Archaeometry 1998, 40, 241-260. [CrossRef]

61. Tite, M.S. The production technology of Italian maiolica: A reassessment. J. Archaeol. Sci. 2009, 36, $2065-2080$. [CrossRef]

62. Blanc, C. Etude Archéométrique de la Faïencerie du Sauvage, Fribourg (1758-1810). Ph.D. Thesis, University of Fribourg, Fribourg, Switzerland, 2007. (In French)

63. Blanc, C. Etude archéométrique. In La fä̈ence de Fribourg (1753-1844); Maggetti, M., Ed.; Faton: Dijon, France, 2007; pp. 82-125, ISBN 978-2-87844-089-8. (In French)

64. Blanc, C. Etude minéralogique et chimique des "terres blanches" de Kilchberg-Schooren. In Die Archäologische Untersuchung in der Ehemaligen Porzellanmanufaktur Kilchberg-Schooren: Monographien der Kantonsarchäologie Zürich 43; Keramikproduktion am linken Zürichseeufer (1763-1906); Matter, A., Ed.; FO-Publishing: Egg bei Zürich, Switzerland, 2012; pp. 41-46. ISBN 978-3-905681-73-4. (In French)

65. Matter, A. Die Archäologische Untersuchung in der Ehemaligen Porzellanmanufaktur Kilchberg-Schooren: Monographien der Kantonsarchäologie Zürich 43; Keramikproduktion am linken Zürichseeufer 1763-1906; FO-Publishing: Zürich, Switzerland, 2012; ISBN 978-3-905681-73-4. (In German)

66. Collomb, P.; Maggetti, M. Dissolution des phosphates présents dans des céramiques contaminées. Rev. d'Archéom. 1996, 20, 69-75. [CrossRef]

67. Maggetti, M.; Serneels, V.; Stasch, G. Composition and technology of 18th century high magnesia faïences from Fulda. J. Archaeol. Sci. Rep. 2015, 2, 40-50. [CrossRef]

68. Schnyder, R. Zürcher Porzellan. Die Figuren der Sammlung Dr. E. S. Kern im Agentenhaus Horgen. Mitt. Keram.-Freunde Schweiz 2009, 122, 8-92. (In German)

69. Maggetti, M.; Morin, G.; Serneels, V. High-Mg faiences from Granges-le-Bourg. In Vessels: Inside and Outside, Proceedings of the Conference EMAC'07, Budapest, Hungary, 24-27 October 2007; Biro, K.T., Szilagyi, V., Kreiter, A., Eds.; Hungarian National Museum: Budapest, Hungary, 2009; pp. 207-216.

70. Maggetti, M.; Rosen, J.; Serneels, V. The origin of 18th-19th century tin-glazed pottery from Lorraine, France. Archaeometry 2015, 57, 426-452. [CrossRef] 
71. Maggetti, M. Glaçures et pigments de la faïencerie Granges-le-Bourg (Haute Saône, France). Analyses et reconstitution technique. In Indices et Traces: La Mémoire des Gestes; Actes du Colloque International 16-18 juin 2011, Nancy, France; Janot, F., Giuliato, G., Morin, D., Eds.; Université de Nancy, Presses Universitaires de Nancy: Nancy, France, 2013; pp. 319-360. (In French)

72. Maggetti, M. Naturwissenschaftliche Charakterisierung von Fayencen aus Fulda. In Made in Fulda. Spitzentechnologie aus der Fuldaer Fayence-Manufaktur (1741-1760); Stasch, G., Ed.; Ausstellungs-Katalog 13.3. 31.5.2015; Vonderaumuseum Fulda: Fulda, Germany, 2015; pp. 125-154. (In German)

73. Maggetti, M. Technologische Analyse zweier Steckborner Ofenkacheln von ca. 1740. Bull. Keram.-Freunde Schweiz 2016, 88, 13-24. (In German)

74. Maggetti, M. Technologische Analyse der Scharffeuerfarben dreier Kachelöfen von der Reichengasse 59 in Freiburg/Schweiz. Bull. Soc. Fribg. Sci. Nat. 2016, 105, 91-119.

75. Maggetti, M.; Galetti, G.; Torche-Julmy, M.T. Analyses scientifiques de quelques catelles de poêles fribourgeois du XVIII' s. Bull. Soc. Fribg. Sci. Nat. 2014, 103, 59-82.

76. Maggetti, M.; Bourgarel, G.; Serneels, V.; Kozlowski, G. Les catelles de trois poêles du XVIII siècle de la maison Grand-Rue 59 à Fribourg. Bull. Soc. Fribg. Sci. Nat. 2015, 104, 74-113.

77. Maggetti, M.; Serneels, V. Cornol, Freiburg, Kilchberg-Schooren oder Matzendorf? Mitt. Keram.-Freunde Schweiz 2015, 129, 63-71. (In German)

78. Maggetti, M.; Serneels, V. Chemische und technologische Analyse einiger Fayencekacheln eines JOHANN BAPTIST NUOFFER zugeschriebenen Kachelofens von ca. 1780-85. Bull. Soc. Fribg. Sci. Nat. 2016, 105, 32-90.

79. Kingery, W.D.; Aronson, M. The glazes of Luca della Robbia. Faenza 1990, 5, 221-225.

(C) 2018 by the author. Licensee MDPI, Basel, Switzerland. This article is an open access article distributed under the terms and conditions of the Creative Commons Attribution (CC BY) license (http:/ / creativecommons.org/licenses/by/4.0/). 